\title{
MAC: A Proposal for Consistent Actuarial Interest Rates in Pension Funds
}

\author{
MAC: Uma Proposta para Metas Atuariais Consistentes em Fundos de Pensão
}

\section{ABSTRACT}

Objective: this article proposes the meta atuarial consistente (MAC) (consistent actuarial rate), which is a method that adjusts incompatible actuarial rates in pension funds, after investigating and proving that the rate dissociates from the general rule in current regulations (which binds this rate to the expected return of the investments of pension funds). Methodology: a sample with data from 22 defined-benefit plans was collected, and MAC was applied to produce consistent actuarial rates, after panel data methods have identified the elements that influence the definition of the actuarial rate by the pension fund board of trustees. Results: the use of MAC, adjusting actuarial rates of 2018 based on systematic biases in previous rates, enabled a positive effect that unfolds in more reliable estimates for the plans' mathematical provision, while identifying elements that influence the determination of the annual rate, causing its non-compliance to the general rule. Conclusion: the adoption of MAC by the Brazilian supervisory authority Previc would improve the rules and provide subsidies to better adjust the contribution levels practiced in the plans, making their solvency levels more reliable, which would benefit the development of the insurance and pension market.

Keywords: actuarial interest rate; pension funds; panel data; insurance and pension market; social security legislation.

\footnotetext{
* Corresponding Author.

1. Universidade Federal Fluminense, Faculdade de Administração e Ciências Contábeis, Departamento de Contabilidade, Niterói, RJ, Brazil

2. Universidade Federal do Rio de Janeiro, Instituto COPPEAD de Administração, Rio de Janeiro, RJ, Brazil.
}

Cite as: Azambuja, S., \& Campani, C. H. (2022). MAC: A proposal for consistent actuarial interest rates in pension funds. Revista de Administração Contemporânea, 26(3), e200390. https://doi.org/10.1590/1982-7849rac2022200390.en

Published as Early Access: October 28, 2021

Assigned to this issue: December 10, 2021.

\section{RESUMO}

Objetivo: viabilizar a proposição de um novo método, a Meta Atuarial Consistente (MAC), que evita, ajustando-as, metas atuariais incompatíveis nos fundos de pensão, após investigar e comprovar, na pesquisa, que a meta dissocia-se da regra geral dos normativos vigentes, que adere essa meta à expectativa de rentabilidade dos investimentos do plano de previdência. Metodologia: foi elaborada uma amostra contendo dados de 22 planos BD, onde aplicou-se a MAC depois de os métodos de dados em painel identificarem os elementos que influenciam a definição da meta atuarial ocorrida no conselho deliberativo dos respectivos fundos de pensão. Resultados: a utilização da MAC, adequando as metas atuariais de 2018 a partir dos vieses sistemáticos ocorridos nas metas anteriores, possibilitou um efeito positivo que se desdobra em estimativas mais fidedignas para as provisōes matemáticas dos planos, ao mesmo tempo que identificou elementos que influenciam na determinaçáo do valor da meta anual, provocando sua não aderência à regra geral da legislaçáo. Conclusóes: a adoção da MAC pela Previc aperfeiçoaria o regramento e forneceria subsídios para melhor adequar os níveis de contribuição praticados nos planos, tornando mais fidedignos seus níveis de solvência, o que beneficiaria o desenvolvimento do mercado de seguros e de previdência.

Palavras-chave: mercado de seguros e previdência; meta atuarial; fundos de pensão; dados em painel; legislação previdenciária. Guest Editors: João Vinícius de França Carvalho (Universidade de São Paulo, FEA, Brazil) (C) Eduardo Flores (Universidade de São Paulo, FEA, Brazil) Emiliano A. Valdez (University of Connecticut, USA) (c) Reviewers: Tatiana Albanez (Universidade de São Paulo, FEA, Brazill) One of the reviewers did not authorize the disclosure of his/her identity. Peer Review Report: The disclosure of the Peer Review Report was not authorized by its reviewers. 


\section{INTRODUCTION}

This article proposes a method to adjust the actuarial interest rate of defined-benefit pension plans (DB) to the general rule provided by current legislation, the consistent actuarial interest rate (MAC). Since 2013, there are indications that the actuarial rate defined annually in pension funds was dissociated from the future returns on their assets. In 2018, 73.4\% of pension fund portfolios were allocated in fixed income and $18.5 \%$ in variable income investment (Associação Brasileira das Entidades Fechadas de Previdência Complementar [ABRAPP], 2018). For Giambiagi and Afonso (2009), Leal and Mendes (2010) and Pereira (2013), the global trend of lower interest rates would reach the Brazilian market, affecting the return of federal government bonds and, consequently, pension funds that used, until 2012, rates equal to or very close to $6 \%$ per annum. Even before the trend pointed out by the authors, Mesa-Lago (2006) warned that the high rates of return on government bonds would not last forever due to the risk of default.

The method proposed in this study adjusts actuarial rates not aligned with the expected return on the pension funds' assets after identifying elements that determined the choice of the pension funds' actuarial rate in a specific period. The method emerged unexpectedly during research using methods of regression in panel data (Fávero, 2013; Marques, 2000) and models of fixed effects applied to historical data from 22 pension plans, a sample drawn from the population of $266 \mathrm{DB}$ plans managed by Brazilian pension funds. The regressions identified the elements that contribute to the choice, ex-ante, of actuarial rates that will prove to be far from the average returns observed expost. MAC makes it possible to adjust the current process of defining the actuarial rate of pension funds - which, according to the research findings, is far from the parameters determined by current legislation. Inaccurate rates result in future contributions (from participants and sponsors) not aligned with the plans' promised benefits. Thus, this research's theoretical contribution lies in the results of the regressions and the adoption of MAC, reducing possible non-adherence of the rates to the returns of the pension funds' financial assets.

This study particularly refers to two research works. First, Santana and Costa (2017) proposed a case study with two approaches to determine the actuarial rate from the data produced in the actuarial valuation of a DB plan. The rate is initially based on the plan's investment portfolio, future return assumptions, and a government bond portfolio with Brazilian federal funds rate forecasts (Selic) obtained in a previous study conducted in 2006. The other approach adopted by Santana and Costa (2017) in their case study was similar to approaches defended by Chapman, Gordon and Speed (2001) and Novy-Marx (2015), based on a lowrisk portfolio.

The second research referred to in this study is Silva, Malaquias and Rech (2020). The authors identified variables that affected returns (represented by the Sharpe ratio) of the portfolios of 310 national pension funds between 2011 and 2018. The assessed return was explained by the administrative fees, fund assets (when the model does not present the rates), the fund's age, and risk and stock diversification indices. Despite the similarities that justify the particular reference to Santana and Costa (2017) and Silva et al. (2020), these studies differ from our research due to some limitations. In the case of Santana and Costa (2017), the study is restricted to a single plan and to a set of assumptions based on rules in force before the current regulations. As for Silva et al. (2020), the authors explain the pension funds' past returns, which, in our view, are far from the defined actuarial rates.

Therefore, as far as we know, this is an innovative research with no similar study published in national or international journals. Its originality lies, firstly, in the fact that we carried out a longitudinal analysis applied to a wide range of data from DB plans sponsored by relevant companies and state-owned enterprises and identified, via panel data methods, factors that influenced the definition of the actuarial rate characteristic of the time frame of the sample. In addition, a decisive contribution of the research is the methodology proposed, MAC, which smoothly calibrates the rates defined in the plans to the complex Brazilian legislation, using deviations calculated among previous rates and returns.

It is worthwhile stressing the social character of pension funds, which is correlated with determining the actuarial rates. Achieving (and preferably surpassing) the desired rate of return is crucial to ensure the benefits a DB plan offers to its participants, who have entrusted their savings, via contract, to the so-called entidades fechadas de previdência complementar (EFPC) ('closed' complementary pension funds are pension funds established by and to serve a particular group - related to an employer, for example). The EFPCs are considered institutional investors capable of providing post-employment financial protection consistent with the contributions made to the plan (Alda, 2018; Binswanger \& Schunk, 2012; Martins-Costa, 2005). In our view, MAC will offer solid bases for the payments of pension benefits to participants of plans managed by entities in a sector that has financial assets equivalent to $13.2 \%$ of the Brazilian GDP (ABRAPP, 2018). 


\section{CONTEXTUALIZATION OF THE RESEARCH}

\section{The importance of the actuarial interest rate}

Insurance companies and pension entities depend on a discount rate to price premiums, contributions, and benefits intended to cover the products offered. This article uses the term actuarial rate, which is how this rate is known for pension funds. It seeks to reproduce the expected return on the investments made with the pension fund's assets designated to cover the plan's benefits. It can be considered a rate that balances benefit payment cash flows to the plan's assets. If the rate rises, the present value of the benefit flows drops, and it is possible to reduce the costing plan level or increase the level of benefits. If the rate drops, the present value of the flows rises, which may imply higher contributions or lower benefits. It is common to establish a hypothesis of a constant actuarial rate; however, it is a particular case of a more general hypothesis varying, in a curve, the rate over time.
The rate is a relevant economic premise of pension plans, defined by the funds' board. Defining this rate is one of the most relevant roles of the pension funds' conselho deliberativo (board of trustees) because the contribution rates and level of benefits depend on this rate gravitating the average of the future return on the plan's assets. A suitable rate offers transparency to the plan's financial health, allowing a reliable comparison of the assets' capacity to cover the benefits with the mathematical (or actuarial) provisions - the sum of the present value of future benefits. Thus, an actuarial liability is estimated against the assets, resulting in a deficit (insufficient assets to pay future benefits), technical balance, or surplus (assets exceed what is necessary to pay benefits). Deficits or surpluses are resolved respectively two and three periods after the occurrence if the rules and limits defined in CNPC Resolution 30, of October 10, 2018 (Resolução 30) expired.

Thus, DB plans imbalances and their respective equalization are necessarily reflected in the financial statements of pension funds and sponsors. Table 1 shows the total annual variable contribution (VC) plans, DB plans, and defined contribution plans from 2010 to 2018, divided by deficit or surplus (ABRAPP, 2018).

Table 1. EFPC pension plans in deficit or surplus per year.

\begin{tabular}{ccccccccccc}
\hline Situation & 2010 & 2011 & 2012 & 2013 & 2014 & 2015 & 2016 & 2017 & 2018 \\
\hline Deficit & 121 & 153 & 111 & 257 & 237 & 239 & 205 & 193 & 199 \\
Surplus & 580 & 550 & 516 & 402 & 417 & 398 & 438 & 437 & 415 \\
\hline
\end{tabular}

In 2018, 199 plans presented a deficit, possibly with uncalibrated actuarial rates. This situation indicates a difficulty for pension funds in estimating a rate consistent with the financial performance of the plan's assets. Between 2012 and 2013, the number of pension plans in deficit more than doubled, while those presenting surplus plans reduced by almost $1 / 4$. The deficit and surpluses leading causes are the difference between the actuarial rate and the effective return on the fund's assets over time. Secondarily, other biometric and economic hypotheses also produce imbalances, but to a much lesser degree. The works of Silva, Chan and Martins (2007) and Sousa and Costa (2015) are consistent with our perceptions. Azambuja and Campani (2019) conducted a sensitivity analysis in the actuarial rate, changing it from $4.5 \%$ to $5.5 \%$. The authors found reductions between $6 \%$ and $9 \%$ in VC plans in a specific year. Levy (2011) indirectly reinforces our conclusions by reporting that reductions of $1 \%$ and $1.4 \%$ in British interest rates in $2006(2.8 \%)$ and $2009(3.2 \%)$ resulted, the following year, in increases of $30 \%$ and $37 \%$ (respectively) in the provisions of the four most extensive government DB plans in the United Kingdom. Although these last variations seem excessive to us - our experience indicates that reductions of one point in rates of $5.5 \%$ increase provisions by up to $20 \%$ - Levy's (2011) finding can be relativized because such excessive variations refer to provisions of data from distinct years. Therefore, depending on the level of the actuarial rate, reductions that seem negligible have the potential to affect mathematical provisions significantly. Finally, we stress that the movement of significant fluctuations in the Selic rate, mentioned in Sartori (2015), persisted in 2020. Curiously, regarding companies sponsoring DB plans, another norm is followed to determine the actuarial rate (now the interest rate) in the accounting provision of the net actuarial obligation (reduced mathematical provisions of assets) of the sponsored plans. It is considered the Statement 33 of the Brazilian Accounting Practice Committee (CPC), which establishes a discount interest rate corresponding to the returns of low-risk bonds with a term of maturity aligned with the plan's duration. Fluctuations in this rate cause relevant changes in the financial statements (Sartori, 2015). Recently (December $31,2018)$, Petrobras (state-owned enterprise) recorded BRL 38.9 billion as a net actuarial obligation, while its sponsored pension fund Petros recorded a deficit equivalent to BRL 8.4 
billion. In the state-owned enterprise's financial statements, the difference was detailed, highlighting the portion of BRL 5.2 billion resulting from adopting a discount rate of $4.9 \%$ p.a., $0.8 \%$ lower than the $5.70 \%$ p.a. rate of Petros (Petrobras, 2019). The MAC method proposed in this study will make it possible to reduce this difference, making obligations more transparent for the sponsors' boards of directors, fiscal committees, and auditing bodies.

\section{Recent regulations and the pension funds' returns}

Limited to $6 \%$ p.a. in 2012 , the actuarial rate was changed by Resolution MPS/CNPC 9, of November 29, 2012, which stipulated new limits with reductions of $0.25 \%$, between 2013 (5.75\% p.a.) and 2018, when it would reach $4.5 \%$ p.a. At the time, long-term rates were set based on short-term market histories, possibly causing false deficits in the pension plans, judging by the total of plans presenting deficits in 2013, as shown in Table 1.

However, the sharp drop in the performance of EFPC investments in the 2013-2014 period due to the global economic crisis resulted in Resolution MPS/CNPC 15, of
November 19, 2014 (Resolução 15), which suspended the ongoing linear reduction. An exception was introduced in the definition of the actuarial rate, an alternative to the rule that stated that the rate would correspond to the expected value of the future return on the plan's asset - considered the general rule in this article. Furthermore, if the rate was not adherent to the exception - a parameter interest rate (parameter rate) obtained from averages of three years of the forward interest rate structure (ETTJ) and located in a predetermined interval (function of the duration of the plan's actuarial liability) - , the EFPC should present a technical study proving the rate's feasibility.

Consequently, we understand that there is now an incentive for the EFPCs not to determine rates associated with the expected performance of their assets but based on limits calculated by the supervisory agency. Table 2 has some of the parameter rates published in 2019 by the National Superintendence of Complementary Pension (Previc). The decision to use the parameter rate allows one to choose values between $70 \%$ of this rate, its lower limit, and the rate plus 40 basis points, the upper limit. The sample has an average of 9.7 years for the duration of DB plans in 2019, which would allow the plan's manager to choose an actuarial rate based on the parameter rate of between $4.09 \%$ and $6.24 \%$.

Table 2. Parameter rate and limits published in 2019.

\begin{tabular}{cccc}
\hline Plan duration (years) & Parameter rate (\% p.a.) & Lower limit (\% p.a.) & Upper limit (\% p.a.) \\
\hline 9.5 & 5.83 & 4.08 & 6.23 \\
10.0 & 5.84 & 4.09 & 6.24 \\
12.0 & 5.85 & 4.09 & 6.25 \\
\hline
\end{tabular}

Note. Parameter rate and limits published in portaria n. 300 (Ordinance 300) on April 30, 2019, at the Diário Oficial da Uniăo (Federal Official Gazette), ed. 82 , p. 53.

Figure 1 reproduces data on the average returns on the assets of EFPCs, excerpts obtained from the 2018 and 2019 consolidated statistical data of ABRAPP, in addition to other information. The limit of $6 \%$ p.a. in effect in 2012 corresponded to a nominal rate of $12.6 \%$ (6\% plus INPC at $6.2 \%)$, located in the TMA/TJP* ${ }^{*}$ INPC value of 2012. TMA means maximum interest rate allowed until 2014, and TJP represents the upper limit of the parameter rate for 2015 onward, with duration of 10 years.

The figures for the returns of EFPCs from 2013 to 2015 - a period where Resolutions 9 and 15 were in force - demonstrate an unsatisfactory performance of the pension funds' financial assets. Nominal returns were, respectively, $3.3 \%, 7.1 \%$, and $5.2 \%$, due to the effects of the global crisis. However, actuarial rates defined in this interval and previous years, chosen based on the limits of TMA/TJP*+INPC, did not capture these performances. Thus, the effect of the financial crisis was felt only in the performance of financial assets, possibly causing deficits to be resolved, but not in the estimates of mathematical provisions.

The waiver of Resolution 15 and the limit of $5.75 \%$ p.a. in 2013 allowed pension funds to choose actuarial rates that were not aligned with what was happening in the financial markets in 2013-2015. This condition resulted in lower mathematical provisions than that calculated using discount rates based on federal bonds available for trading at that moment. Therefore, the deficits and possible solutions that emerged would be higher if the rates had incorporated the returns obtained during the financial crises. This same reasoning is valid for rates defined before 2013. If they included the significant reduction in returns observed between 2013 and 2015 , post-equalization would be carried out, resulting in more solid assets to face the crisis that began in 2013. 


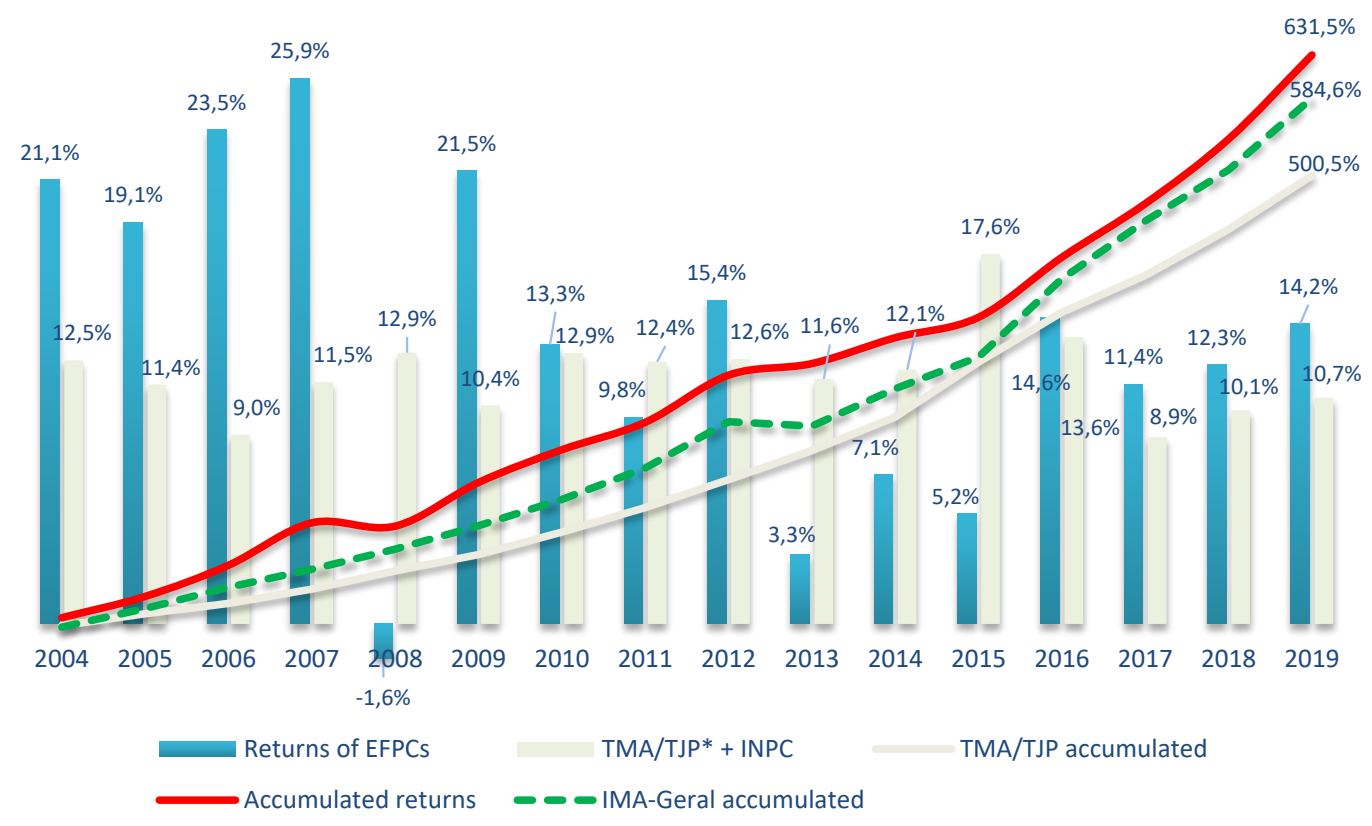

Figure 1. Comparative performance of the returns of EFPCs in the period 2004-2019.

Bars represent the average nominal returns of EFPCs compared to the limits for nominal actuarial rates. The curves show the accumulated returns, the Brazilian benchmark rate IMA-Geral, and the limits of actuarial rates. All values include inflation. In December 2019, the data represented the return of pension plans managed by 245 EFPCs. Source: Associaçáo Brasileira das Entidades Fechadas de Previdência Complementar [ABRAPP] (2019).

One of the effects of the mathematical provisions not having reflected the reduced profitability from 2013 to 2015 is the approximation, after 2014, between the curve of benchmark IMA-Geral accumulated Brazilian Association of Financial and Capital Market
Entities (Anbima) - and the curve of accumulated returns (Figure 1). Figure 2 was prepared based on data from Figure 1, referring to the period from 2012 to 2019 , net of inflation, allowing a closer look at the assets' performance.

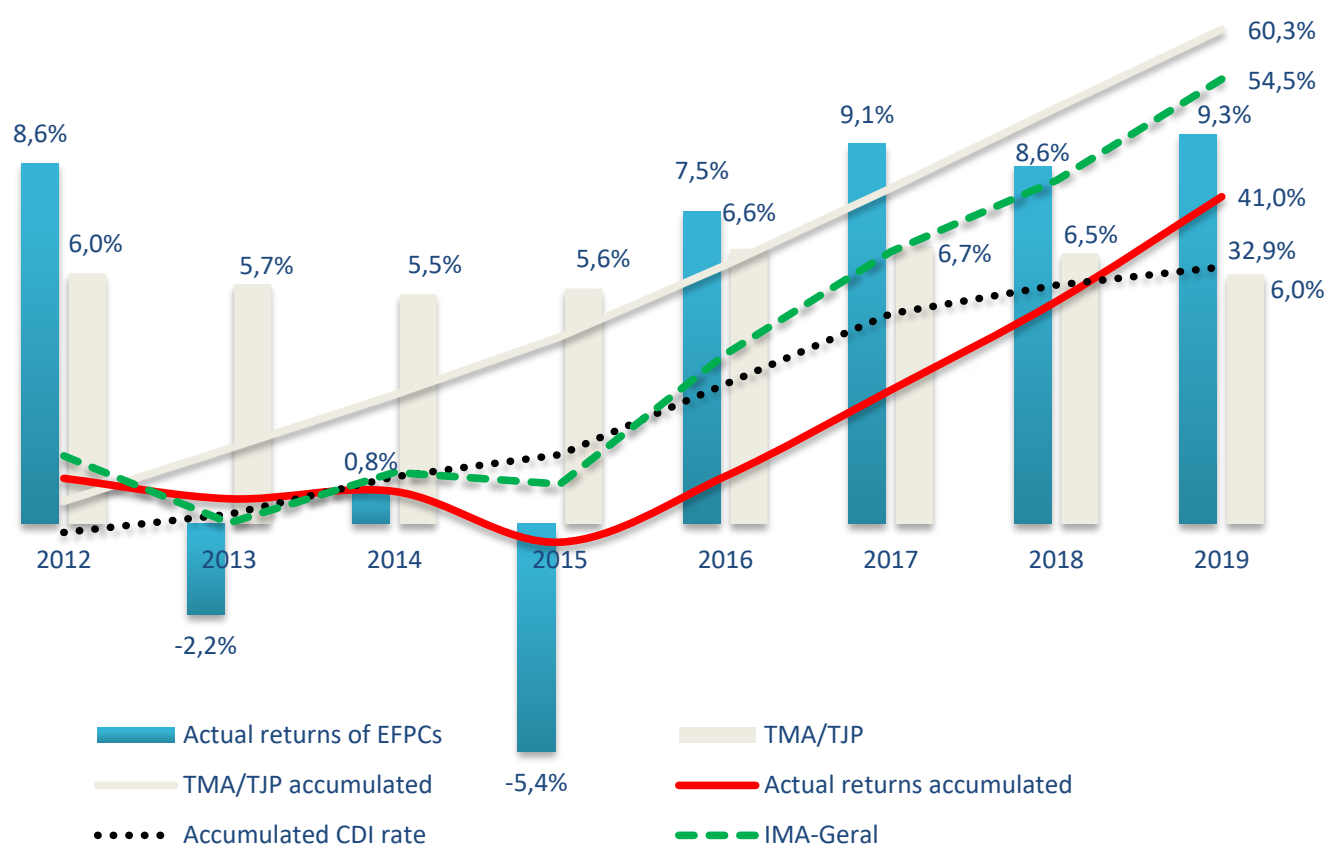

Figure 2. Comparative performance of the returns of EFPCs in the period 2012-2019.

Bars represent the average actual returns of EFPCs compared to the limits for actuarial rates according to the rules (TMA/TJP). The curves allow comparing the Brazilian benchmark rates CDI and IMA-Geral (net of IPCA index of inflation) to the values of accumulated returns and TMA/TJP (net of INPC index of inflation). 
It was possible to observe that the accumulated return of the EFPCs was often below the IMA-Geral, surpassing it only in 2013. As for the accumulated values, IMA-Geral extrapolated by $33 \%$ ( $55 \%$ versus $41 \%$ ) the returns of the EFPCs. When comparing the returns to the benchmark CDI rate, they surpassed it in 2012, 2013, and 2019. When considering the accumulated values, the CDI rate was surpassed by $25 \%$ ( $41 \%$ versus $33 \%$ ). The average value of the actual return of the EFPCs, net of the inflation (INPC), corresponded to $4.5 \%$ p.a. in the interval shown in Figure 2 , above the average CDI rate (3.6\%) and below the average IMA-Geral - usual benchmarks for fixed income (Lima, 2006). However, when looking at the curve corresponding to the accumulated TMP/TJP values, it is clear that the values of the parameter rate are not feasible, as they seem to assume that the financial performance of EFPCs' investments is not subject to market fluctuations. Resolution 30 unified regulations and presented rules already in place for defining the actuarial rate in the EFPC. Its specific changes maintained the responsibilities and obligations of the governance bodies and the general rule that determined the discount rate as the expected value of the future returns of the plan's assets. However, the ETTJ calculation interval was changed from three to five years, aggravating a possible use of the parameter rate originated from average daily interest rates on federal government bonds indexed to the inflation (IPCA) with a base date of April 1 (which will be nine months out of date on December 31).

\section{Sample database}

The research data were collected from the Demonstração Atuarial de Encerramento do Exercício (DA) (actuarial statement provided at the end of the fiscal year) from years 2013 to 2018, obtained in the website of access to information (Superintendência Nacional de Previdência Complementar [Previc], 2020). Complementary data were retrieved from the Annual Information Reports (RAI) of the EFPCs (available on their websites), allowing access to 2019 information for some pension plans. The research used data from 22 plans, managed by the EFPCs Petros, Fachesf, Fundação Real Grandeza, Funcef, Eletrocee, Forluz, Banesprev, Funcesp, Valia, Telos, Sistel, Previ, Funbep, Usiminas, Centrus, Fundação Copel, Braslight, Previrb, and Fundação Itaú Unibanco. The choice of plans combined the ranking of the 15 largest (14 are in the sample) with another seven pension fund plans, belonging to the group of the 25 funds with the most significant assets (ABRAPP, 2018).

The plans' actuarial provisions totaled BRL 365 billion, while their assets reached BRL 364.6 billion (64\% of all DB plans in 2018). Other elements made up the base: benefit inflation rates, parameter rates and their limits, Ibovespa values, NTN-B bond rates, and the board of trustees' composition. The board members can influence the definition of the actuarial rate, as indicated by Andonov, Bauer and Cremers (2017), because it is expected that a board member who retires will represent the interests of beneficiaries instead of those of sponsors or active plan members.

Table 3 shows part of the PBB and REG/Replan, managed respectively by the EFPCs Centrus and Funcef, administrators of plans of the Brazilian Central Bank and the federal state-owned bank Caixa Econômica.

Table 3. Data from PBB and REG/Replan.

\begin{tabular}{|c|c|c|c|c|c|c|c|c|c|c|c|}
\hline \multicolumn{12}{|c|}{ PBB - Centrus } \\
\hline \multirow[b]{2}{*}{ Year } & \multirow{2}{*}{$\begin{array}{l}\text { Actuarial } \\
\text { rate }\end{array}$} & \multirow[b]{2}{*}{ Dur } & \multirow[b]{2}{*}{ Par/rate } & \multirow[b]{2}{*}{ Return } & \multirow[b]{2}{*}{ Provisions } & \multirow[b]{2}{*}{ Asset } & \multirow[b]{2}{*}{ SR } & \multirow[b]{2}{*}{ Participants } & \multicolumn{3}{|c|}{ Board members appointed/elected by: } \\
\hline & & & & & & & & & Sponsors & $\frac{\text { Beneficia- }}{\underline{\text { ries }}}$ & $\begin{array}{c}\text { Active } \\
\text { members }\end{array}$ \\
\hline 2013 & $4.0 \%$ & 8.0 & $5.75 \%$ & $-2.87 \%$ & $3,353,044$ & $4,800,974$ & 1.4 & 1,404 & 3 & 3 & - \\
\hline 2014 & $4.0 \%$ & 8.4 & $5.07 \%$ & $-2.06 \%$ & $3,433,141$ & $5,015,403$ & 1.5 & 1,450 & 4 & 2 & - \\
\hline 2015 & $4.5 \%$ & 8.2 & $5.19 \%$ & $0.68 \%$ & $3,436,910$ & $5,240,494$ & 1.5 & 1,419 & 3 & 3 & - \\
\hline 2016 & $4.5 \%$ & 8.1 & $6.16 \%$ & $10.31 \%$ & $3,476,140$ & $5,099,284$ & 1.5 & 1,378 & 3 & 3 & - \\
\hline 2017 & $4.5 \%$ & 8.0 & $6.27 \%$ & $6.73 \%$ & $3,381,290$ & $5,179,000$ & 1.5 & 1,331 & 3 & 3 & - \\
\hline 2018 & $4.5 \%$ & 7.8 & $5.99 \%$ & $6.93 \%$ & $3,306,601$ & $5,190,708$ & 1.6 & 1,295 & 2 & 4 & - \\
\hline Averages & $4.3 \%$ & 8.1 & $5.74 \%$ & $3.3 \%$ & $3,397,854$ & $5,087,644$ & 1.5 & 1,380 & 3 & 3 & - \\
\hline SD & $0.26 \%$ & 0.2 & $0.50 \%$ & $5.44 \%$ & 62,463 & 161,161 & 0.05 & 58 & 0.6 & 0.6 & - \\
\hline Coeff & $6 \%$ & $2.5 \%$ & $8.8 \%$ & $165 \%$ & $1.8 \%$ & $3.2 \%$ & $3.5 \%$ & $4.2 \%$ & $21 \%$ & $21 \%$ & - \\
\hline
\end{tabular}


Table 3. Data from PBB and REG/Replan (Continued).

\begin{tabular}{|c|c|c|c|c|c|c|c|c|c|c|c|}
\hline \multicolumn{12}{|c|}{ REG/Replan of Funcef } \\
\hline \multirow[b]{2}{*}{ Year } & \multirow{2}{*}{$\begin{array}{l}\text { Actuarial } \\
\text { rate }\end{array}$} & \multirow[b]{2}{*}{ Dur } & \multirow[b]{2}{*}{ Par/rate } & \multirow[b]{2}{*}{ Return } & \multirow[b]{2}{*}{ Provisions } & \multirow[b]{2}{*}{ Asset } & \multirow[b]{2}{*}{ SR } & \multirow[b]{2}{*}{ Participants } & \multicolumn{3}{|c|}{ Board members appointed/elected by: } \\
\hline & & & & & & & & & Sponsors & $\frac{\text { Beneficia- }}{\underline{\text { ries }}}$ & $\begin{array}{c}\text { Active } \\
\text { members }\end{array}$ \\
\hline 2013 & $5.5 \%$ & 13.5 & $5.75 \%$ & $1.27 \%$ & $44,850,735$ & $41,709,336$ & 0.9 & 63,575 & 3 & 2 & 1 \\
\hline 2014 & $5.6 \%$ & 14.0 & $5.27 \%$ & $-1.99 \%$ & $47,098,783$ & $40,563,207$ & 0.9 & 63,343 & 3 & 2 & 1 \\
\hline 2015 & $5.6 \%$ & 13.2 & $5.36 \%$ & $-7.17 \%$ & $51,095,967$ & $38,835,508$ & 0.8 & 63,110 & 3 & 2 & 1 \\
\hline 2016 & $5.5 \%$ & 13.4 & $6.22 \%$ & $-1.66 \%$ & $49,592,887$ & $37,296,713$ & 0.8 & 64,240 & 3 & 2 & 1 \\
\hline 2017 & $4.5 \%$ & 15.1 & $6.24 \%$ & $10.44 \%$ & $47,857,628$ & $41,528,278$ & 0.9 & 66,473 & 3 & 2 & 1 \\
\hline 2018 & $4.5 \%$ & 13.7 & $5.97 \%$ & $7.54 \%$ & $49,439,052$ & $44,427,168$ & 0.9 & 62,807 & 3 & 2 & 1 \\
\hline Averages & $5.2 \%$ & 13.8 & $5.80 \%$ & $1.4 \%$ & $48,322,509$ & $40,726,701$ & 0.8 & 63,925 & 3 & 2 & 1 \\
\hline SD & $0.55 \%$ & 0.7 & $0.42 \%$ & $6.54 \%$ & $2,205,422$ & $2,476,679$ & 0.07 & 1,340 & - & - & - \\
\hline Coeff & $10.6 \%$ & $5 \%$ & $7.2 \%$ & $465 \%$ & $4.6 \%$ & $6.1 \%$ & $8.7 \%$ & $2.1 \%$ & - & - & - \\
\hline
\end{tabular}

Note. This table presents data from the PBB and REG/Replan. The Actuarial rate column shows the discount rate used to calculate plan provisions. Par/rate values correspond to the parameter rate associated with the years of duration (Dur) or the limit of the actuarial rate. Return refers to the actual return on assets for the year. Provisions represent amounts (in BRL thousand) of the plan's mathematical provisions. Assets are represented in BRL thousand. SR represents the plan's solvency ratio (ratio between assets and provisions). Participants are the total plan members (beneficiaries and active members). The last columns correspond to the number of board members appointed or elected by Sponsors, beneficiaries, and active members. The line 'averages' contains the simple averages of the annual data, while the lines SD and Coeff represent standard deviations and coefficients of variation, respectively.

Table 3 shows stability in the actuarial rates, limited to $4.5 \%$ p.a. of $\mathrm{PBB}$, which is in extinction (there are no active members) and surplus, as observed from the solvency ratios (SR). REG/Replan, on the other hand, is a deficit plan composed of active members and beneficiaries, presenting actuarial rates that vary between $4.5 \%$ and $5.6 \%$ p.a.

The data presented shows that PBB has an average actuarial rate $1 \%$ higher than the average return on its asset $(4.3 \%$ versus $3.3 \%)$ and well below the average parameter rate for the period, $5.74 \%$. The coefficient of variation of the actuarial rate $(6 \%)$, compared to the coefficient regarding returns $(165 \%$, indicating heterogeneous data), leads to the conclusion that the coefficients refer to different samples. The same occurs when comparing the coefficients of provisions $(1.8 \%)$ and coefficient of returns. These facts may indicate that the administrator Centrus chose not to reduce its rates, thus avoiding possible equalization that would affect participants and sponsors. Another possibility is that the actuarial rate will avoid values allowed by the parameter rates, which could give rise to the distribution of financial surplus to participants and sponsors.

The information about REG/Regplan (Table 3) suggests that the average actuarial rate is close to the average of the parameter rates $(5.8 \%)$ but far from the average of the returns on assets (1.4\%), which has a coefficient of variation $(6.1 \%)$ dissociated from the coefficient of the actuarial rate $(465 \%)$. A similar fact occurs with the coefficient of asset variation (6.1\%) regarding the coefficient of returns. However, in this case, the coefficient of asset variation is close to the coefficients of provisions $(4.6 \%)$ and parameter rate $(7.2 \%)$. These phenomena corroborate that the actuarial rate chosen by the Funcef's board used the opportunity the regulation offered to adopt the parameter rate, most likely due to the presence of a persistent deficit due to low returns obtained, which resulted in actuarial rates and provisions not achieved by the returns on the plan's asset. The definition of higher rates in intervals of reduced returns suggests a repetition of the phenomena found in Pennacchi and Rastad (2011), who, between 2000 and 2009, identified that 125 US state pension funds chose to buy more risk in asset portfolios after periods of relatively poor investment performance. Table 4 contains the base statistics, enabling a summarized view of these values.

In turn, Figure 3 contains information that allows a more detailed analysis about the average values, each year, of the actuarial rate, the parameter rate corresponding to the duration, return on assets, and expected return for that year, defined in the pension funds, from the data found in the DA or RAI. 
Table 4. Descriptive statistics of the main variables.

\begin{tabular}{|c|c|c|c|c|c|c|c|c|}
\hline \multirow{2}{*}{$\begin{array}{c}\text { Period } \\
\text { Variable }\end{array}$} & \multicolumn{8}{|c|}{ 2013-2018 } \\
\hline & Minimum & $1^{\text {st }}$ Quartile & Average & Median & $3^{\text {rd }}$ Quartile & Maximum & $\begin{array}{l}\text { Standard } \\
\text { deviation }\end{array}$ & $\begin{array}{c}\text { Coefficient of } \\
\text { variation }\end{array}$ \\
\hline Actuarial rate & $3.8 \%$ & $4.5 \%$ & $5.28 \%$ & $5.5 \%$ & $5.7 \%$ & $10.7 \%$ & $1.14 \%$ & $22 \%$ \\
\hline Duration & 6.8 & 9.2 & 10.7 & 9.9 & 11.5 & 22 & 2.85 & $30 \%$ \\
\hline $\begin{array}{l}\text { Provision } \\
\text { (BRL million) }\end{array}$ & 181.5 & 2,229 & 15,727 & 5,073 & 7,637 & 154,506 & 31,400 & $200 \%$ \\
\hline $\begin{array}{c}\text { Asset } \\
\text { (BRL million) }\end{array}$ & 230 & 2,690 & 15,144 & 5,113 & 8,637 & 161,031 & 30,064 & $200 \%$ \\
\hline Annual return & $-14.4 \%$ & $1.2 \%$ & $4.4 \%$ & $5.84 \%$ & $7.91 \%$ & $16.38 \%$ & $6.48 \%$ & $147 \%$ \\
\hline Solvency ratio & 0.62 & 0.92 & 1.07 & 1 & 1.21 & 1.69 & 0.21 & $19 \%$ \\
\hline Parameter rate & $5.04 \%$ & $5.3 \%$ & $5.78 \%$ & $5.97 \%$ & $6.2 \%$ & $6.3 \%$ & $0.42 \%$ & $7.3 \%$ \\
\hline $\begin{array}{l}\text { Active plan } \\
\text { members }\end{array}$ & 0 & 10 & 3,611 & 597 & 2,956 & 28,754 & 6,974 & $193 \%$ \\
\hline Beneficiaries & 16 & 3,670 & 15,171 & 6,878 & 12,280 & 100,397 & 22,079 & $145 \%$ \\
\hline
\end{tabular}

Note. Basic statistics are presented for the variables of the 22 DB plans, calculated for the period 2013 to 2018. The columns "1st Quartile" and "3rd Quartile" correspond to the first and third quartiles of the values of each variable. The amounts related to provisions and equity are in millions of Brazilian Reais (BRL).

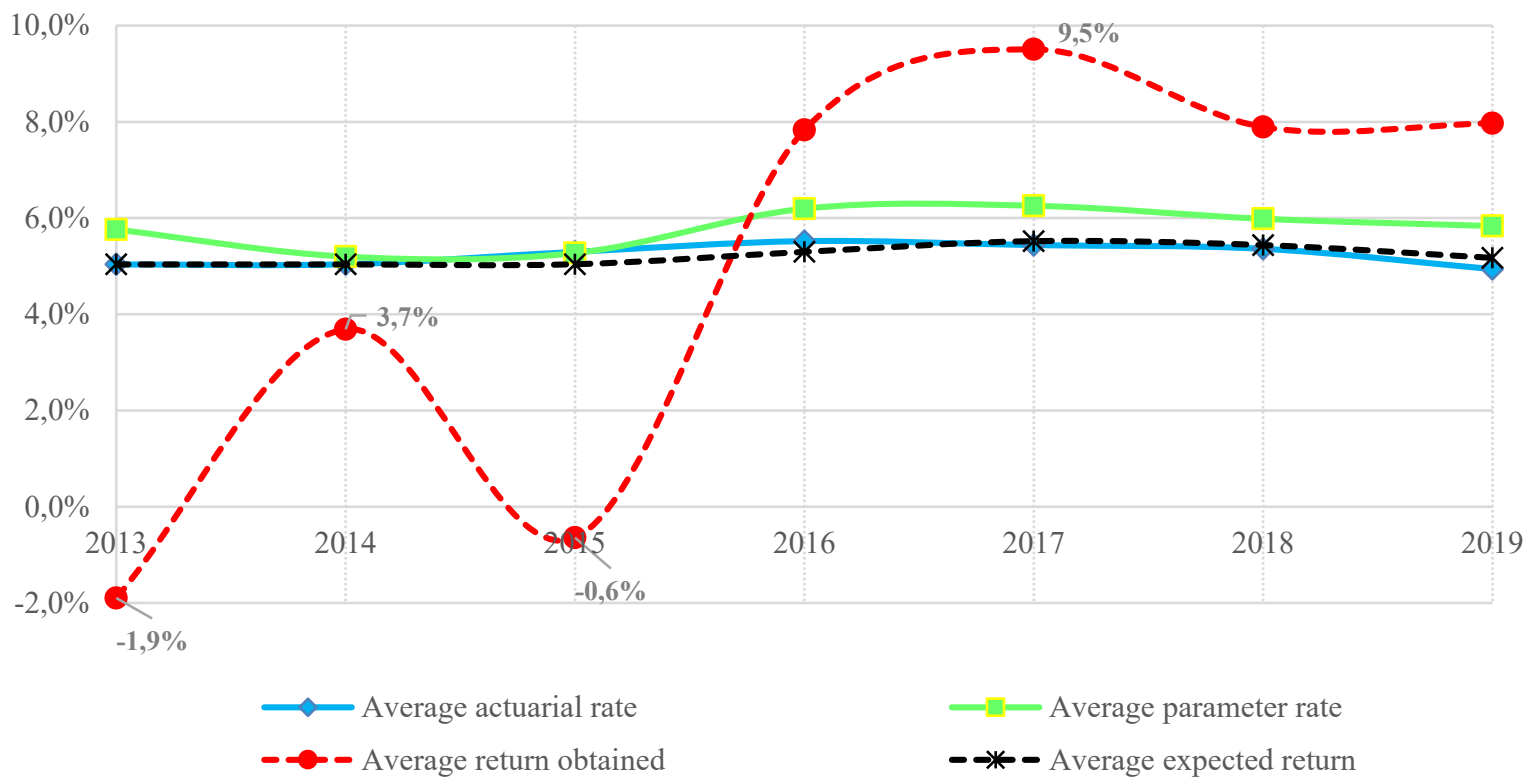

Figure 3. Averages of actuarial rates, actual return obtained, parameter rates, and expected return in each period for the $22 \mathrm{DB}$ plans in the sample base.

The curves correspond to the averages of the values in the data of the plans researched. In 2019, the data referred to only nine of the 22 plans. The expected average return corresponds to the actuarial rate in effect in the immediately preceding year. The benchmark rate for 2013 presents the maximum value allowed of $5.75 \%$. All values are net of inflation.

The performance of the average actuarial rates observed in Figure 3 is almost identical to the curve of average expected returns for the same interval, which indicates a very low oscillation of the target between subsequent years. The curve related to the parameter rates is graphically more adherent to the curve of the rates in the years 2013 to 2015, the interval in which the parameter rate started to be gradually adopted by EFPCs. These curves remained similar between 2016 and 2019, possibly indicating greater adherence to the new methodology by part of the EFPCs. When looking at the average values of actual returns each year (the most sinuous curve), there are 
practically no similarities for the curves representing the other averages. Therefore, it is unlikely to infer that the actuarial rates are related to the returns on the plans' assets in the period presented.

In pension funds, the use of actuarial rates higher than the rates of return on assets postpones potential equalization of financial imbalances, which might appear if the chosen rates were similar to the average values of the future returns of the plan's investment portfolio. Figure 3 shows that the averages for the actuarial rates, parameter rates, and returns are, respectively, 5.26\%, 5.78\%, and $4.6 \%$ in the period. Therefore, the average return is $13 \%$ lower than the average rate adopted. According to the supervisory authority Superintendência Nacional de Previdência Complementar (Previc) (2019) in 304 DB plans, the average actuarial rates reached $5.30 \%$ p.a. in 2018 , similar to the average $5.36 \%$ calculated in the research sample for the same year, reinforcing the database relevance and representativeness.

\section{THEORETICAL FRAMEWORK AND EMPIRICAL LITERATURE}

The literature on methods to estimate pension plans' actuarial rates, including alternative proposals, has been, in general, descriptive and not very assertive. The comprehensive literature gathered by the US Congress agency Government Accountability Office (GAO) (2014) stands out. The agency conducted extensive research on the actuarial rate of pension plans in the US, Canada, the Netherlands, and the UK. It adopted two main methods, the assumed-return approach and the bond-based approach, which are similar to the techniques used for Brazilian DB plans: actuarial rates based on the future returns obtained from the pension plan's investment portfolio or based on discount rates from average returns of government bonds. Similarly, we structured this theoretical framework and empirical literature section considering these two approaches and including a third subsection gathering studies using other methods.

\section{Actuarial rate based on the returns of the pension plan's investment portfolio}

GAO (2014) described the assumed-return methodology as the specification of a rate associated with the expected long-term performance of the investments in the portfolio of the researched plans, comprising significant portions of stocks and corporate bonds. According to the organization, plans sponsored by state-owned enterprises, government entities, or multi-sponsored entities use assumed-return.
The construction of the actuarial rate in the EFPC ideally starts with the dynamic decision process made possible by asset liability management (ALM) to estimate annual returns on assets according to the portfolio's defined strategic allocation. The estimation will discount the benefits of future long-term flows (30 years at least) and net contributions, aiming to reflect the average of these returns at a sufficiently high rate to support the payment of future benefits (Bertucci, Souza, \& Félix, 2006; Haneveld, Streutker, \& Van Der Vlerk, 2010; Santos \& Lima, 2019; Silva, Chan, \& Martins, 2007). For Bertucci, Souza and Félix (2006) and Corrêa (2018) after defining the rate, it will direct the returns on the plan's portfolio, adjusting ALM to seek reduced actuarial and financial risks. However, De La Peña, Garayeta and Iturriscastillo (2017) warn that adjusting the initial portfolio that has sought immunization with the cash flow matching method adopted in some EFPCs could result in periods where the available assets - transferable to cash — are insufficient to pay the benefits.

After the ALM process, the methodology commonly used is the internal rate of return (IRR), which allows finding the pension funds' actuarial rate by calculating an IRR that composes a discount factor and adjusts to present value flows of expenses with social security benefits or the payment of amounts insured (Hansen \& Miltersen, 2002). The sum of these current flows corresponds to the asset of a pension plan. In this context, Equation 1 is generic, and its solution represents the actuarial rate $\theta$. The equation is solved computationally by the Newton-Raphson method. A value of $\theta$ can be interpreted as a minimum annual return on asset $(p)$, which is sufficient to cover expenses with benefits (FlowExpenBenef ${ }_{i}$ ), considering net contributions from participants and sponsors.

$\rho=\sum_{i=1}^{n}\left[\left(\right.\right.$ FlowExpenBenef $\left.\left.f_{i} /(1+\theta)^{i}\right)\right] ; i=1, \ldots, n$ years $(1)$

Historically, post-employment benefit accrual began in 1956 in the US and in 1983 in Europe. However, until the end of 2000, Brazilian companies registered benefits on a cash basis (Silva, Tinoco, \& Vieira, 2015). According to Vittas (2010), financial assets were priced at book value until 1960, influencing actuaries to use this model both for plans' assets and liabilities. With the change in this practice, assets are currently evaluated at market value and compared with liabilities for future expenses, discounted to present value at a rate equivalent to the historical average return on investments. At the start, this change generated a conflict between the volatility of the assets' market prices - a short-term characteristic - and the nature of pension liabilities, which is an important characteristic in the medium and long term. 
Andonov et al. (2017) identified a more discretionary US legislation for government pension funds than the one regulating private funds, which encourages managers to invest more in risky assets to produce a higher actuarial rate due to legislation linking the rate to the expected return on the plan's asset. This behavior is favorable to sponsors and participants as it avoids communications to the market about the plan's inadequate financial conditions, which could lead to a review of the cost, maximizing contributions, and harmful exposure to public opinion or review of benefits. The authors analyzed 863 entities, and their DB plans in the US, Canada, the UK, and the Netherlands, between 1990 and 2012, with assets estimated at 29\% of global DB plan assets. The authors highlighted that the US government pension funds exposed to risky assets (public equity, alternative assets, and securities rating below BBB-) have a higher level of underfunding per participant.

In the last years, the decline in interest rates in the countries' economies impacted the pension funds' investment policy, which had to diversify their portfolios to meet the actuarial target. Leal and Mendes (2010) had already predicted that the reduction in rates observed in other countries would also reach Brazil. The authors researched the feasibility of investment allocation strategies in multimarket funds compared to the usual allocations of Brazilian funds, proving that there are advantages in adopting investments in hedge-funds, a standard method in foreign pension funds. The authors concluded that this diversification would improve the risk-return ratio, allowing for a smaller rebalancing of the portfolio and making it possible to reach the then actuarial rate limit with less risk.

Perhaps the big question in pension funds is the choice between a pre-fixed rate - from a range of rates defined in the rules - or a technically proposed rate, representing the actual rate of return expected for the plan's equity. It seems logical to use the expected return on assets as a rate, according to market parameters, but we understand that there is the risk that the fund's manager remains in passive management after reaching the established rate, avoiding unnecessary risking of assets, which is a situation defended by Nese (2017). However, if the actuarial rate is somehow limited, artificial deficits may arise due to the underestimation of long-term returns, which may represent, at first, the collection of contribution levels above that necessary, withdrawing resources from the participants and sponsors. It is not ideal when the rate guides the pension plan's investment because there will be pressure for greater risk-taking. In our view, the investment portfolio may be guided by the actuarial rate as long as contributions and levels of the plans are adequate to the country's social security and fiscal situation. We explain: regular pensions in DB plans before the age of 55 or with less than 35 years of contribution are not tenable, while most of the population contributing to the government social security (INSS) will only retire after 60 .

\section{Actuarial rate estimated by the return from low-risk corporate bonds}

When the pension fund has a single sponsor that is not a state-owned or public entity, the actuarial rate is estimated using the bond-based methodology and its variations (Government Accountability Office [GAO], 2014). Thus, the rate represents the corporate bonds discount rates, whose terms correspond to the same term expected for the benefits, with the possibility of smoothing rate based on historical averages. A variation of the bond-based approach calculates the rate based on prospective government's bond rates. A more complex bond-based approach estimates an actuarial rate after matching the credit quality of corporate bonds with the risk of payment of promised benefits, which also includes using historical municipal bonds yields and calculating a specific actuarial target for solving deficits in the US pension funds. The last variation of this approach is based on the Pension Benefit Guaranty Corporation (PBGC), a North American insurance agency that provides financial assistance or termination of the plans. In the PBGC, bondbased produces a rate according to actuarial annuities traded in a specific market with discount rates associated with marked-to-market bonds, which immunize financial and longevity risks.

In addition to the combination of ALM and IRR, parametric and non-parametric models make up the other methodologies used to estimate the actuarial rate associated with the corporate bond yield. The results produced in the models can often directly represent the rate and serve as an input for the future returns of part of the portfolio for ALM. Varga (2009) and Duarte, Silva, Oliveira, Weffort and Chan (2015) researched methods used by EFPCs in determining the rate, similar to those adopted in applying the liability adequacy test to technical provisions in the insurance market. Such methods consist of modeling a future yield curve, represented by the ETTJ, formed by a set of points in the zero-coupon spot interest rate space, $i(t)$, versus the term, $t$, representing its maturity or duration. The relationship between spot rates and durations produces unobservable ETTJ conditions as it is unlikely to be built by simply observing traded bonds. These situations are solved by statistical models, parametric and non-parametric (spline), which estimate these rates based on existing durations. Parametric models produce a curve that 
provides the best description for the observed ETTJ yield curve, resulting from economic theories of expectations, market segmentation, and preference, even if the curve produced does not meet all points of the real curve. Spline methods seek the exact interpolation to generate the best way to describe the observed rates, using polynomials for sectioned interpolation applied to a set of points formed by the interest rate and duration, or by the rate and respective price of the security, producing a curve that touches all points. The pension market frequently uses the Svensson parametric model, an extension of the Nelson and Siegel model at the cost of being less parsimonious (Caldeira, 2011). This model produces, for a stipulated period, an intraday interest rate originated from an ETTJ curve. This curve is built by parameters of the model, based on market values of government bonds, and published daily (Associação Brasileira das Entidades dos Mercados Financeiro e de Capitais [Anbima], 2017). This model is represented by Equation 2.

$$
r_{t}(\tau)=\beta_{1 t}+\beta_{2 t}\left(\frac{1-e^{-\lambda_{1 t} \tau}}{\lambda_{1 t} \tau}\right)+\beta_{3 t}\left(\frac{1-e^{-\lambda_{1 t} \tau}}{\lambda_{1 t} \tau}-e^{-\lambda_{1 t} \tau}\right)+\beta_{4 t}\left(\frac{1-e^{-\lambda_{2 t} \tau}}{\lambda_{2 t} \tau}-e^{-\lambda_{2 t} \tau}\right)
$$

The first two coefficients are the level $(\beta 1)$ and the inclination ( $\beta 2)$, followed by the $\beta 3$ and $\beta 4$ curves, while $\lambda 1$ and $\lambda 2$ are the discount rates weighted by the previous curvatures to reach the maximum points. These parameters are calibrated utilizing a process to minimize errors between the prices observed in the market and the prices calculated by the model. An alternative to Svensson is the HJM model, cited in Kimura (2019), which projects a forward rate curve based on the term structure generated by stochastic processes.

Santana and Costa (2017) discounted 15-year pension flows by the expected yield of a hypothetical portfolio, consisting of government bonds under negotiation, with future Selic rates obtained from data published in 2006. However, the authors did not verify whether the alternative produced adequate rates according to the legislation, which is restricted since its elaboration considers data from a single year, generated by an invariant set of biometric and economic assumptions, as well as using specific Selic projections.

We believe that the returns obtained by federal bonds largely follow variations of the Selic rate, which is altered by the Brazilian Central Bank to (among other reasons) fight inflation or mitigate losses due to the increase in country risk. In theory, a high Selic benefits the pension fund's returns, but it also affects aggregate demand and domestic growth rates, generating more significant economic problems (Attilio, 2020; Libânio, 2010).

Motta and Santoro (2003) and Silva, Drumond, Silva, Pereira and Oliveira (2016) observed that DB plans incur actuarial risk due to mismatching assumptions, generating a difference between actuarial liabilities and assets, and making the cost of benefits exceeding the estimated (this is aggravated if investments yield less than expected). Saad and Ribeiro (2004) addressed these problems by immunizing a multi-sponsored pension fund portfolio, adapting the plan's ALM models to meet future cash flows. The volatility of the discount rate is the primary driver of the risks mentioned above. For Silva, Tinoco and Vieira (2015) the law determines that part of these risks fall on the DB plan sponsor.

For Chapman et al. (2001) there is an equivalence between any cash flow and a corresponding asset. Therefore, pension liabilities may be priced based on a portfolio of low-risk bonds. Novy-Marx (2015) adheres to this reasoning when defending that the principles of financial economics support the need for the discount rate to be as the expected rate of return of the hedge portfolio, whose flows will correspond to the liabilities flow. Reinforcing this line of thought, Bader and Gold (2003) disagree with studies that advocate a discount rate identical to the one that will make the assets grow in the long run. They point out that this traditional approach contradicts the financial theory because pension plan assets and liabilities pose different risks and should not be assessed in the same way. For the authors, the portfolio could avoid Bicalho's (2018) findings, which observed cumulative returns of EFPCs, between 2010 and 2015, slightly below the CDI rate, with loss-making results on average.

Between 2010 and 2012, the World Bank and the supervisory authority Previc collaborated in building risk-based supervision for EFPCs. It was the beginning of the evolution of the regulations highlighted in this work, establishing rules for actuarial rates associated with the rates of bonds issued by the Brazilian Treasury. For the World Bank (2012), Brazilian DB plans presented risks related to the absence of governance that would oversee the chosen assumptions, the independence of actuaries, and the adoption of high rates. For the World Bank, as 
board members and managers of EFPCs are rarely held responsible for assumptions, the evasion of responsibility provides conflicts of interest in management and high discretion in the board of trustees, allowing it to disregard technically defined parameters. Double-digit historical real returns allowed sufficient margins to absorb, or hide, deviations in other assumptions when there was a $6 \%$ threshold. This complacency made the boards resistant to reductions in actuarial rates, despite the stabilization of real interest rates on government bonds. The World Bank (2012) concluded that risk-based supervision would reduce problems by using discount rates that are aligned with the expectations of the return on the plans' investments, linked to the rates of short-, medium-, and long-duration bonds.

We understand that the definition of an actuarial rate of the bond-based type - based on the yields of low-risk bonds, whether retrospective as made possible by Resolution 30, or prospective, as advocated in the literature presented - should be used as the last management option in the case of pension funds' assets. The definition of these rates constitutes, in our analysis, a contradictory effort in investment management, disfavoring specialized academic literature and wellestablished investment techniques in exchange for the security of a minimum return. Also, such a definition excessively compromises the capital of participants and sponsors, possibly removing it from the formal economy by demanding more contributions due to the expected increases in mathematical provisions.

Reinforcing our considerations, Leal and Mendes (2010) demonstrated the reasonableness of investment strategies with returns above the financial market benchmarks. CMN Resolution 4,661 of May 25, 2018, presents a list of possibilities to allocate the pension funds' financial assets, including maximum limits. The resolution allows forming portfolios with investments in the segments structured, real estate, operations with participants and abroad, in addition to traditional fixed and variable income. The conditions to seek gains above the returns of low-risk bonds are documented in the literature and legally accepted. They are facilitated since most pension funds have conditions to form and maintain investment teams with specialists in these segments.

\section{Other ways to determine the actuarial rate}

The discount interest rate (actuarial rate) is one of the central components in the definition of actuarial and insurance annuities used in actuarial calculations. Few authors described methodologies to define this interest rate in publications targeted to undergraduate and graduate programs focused on areas such as insurance and pensions. Norberg (2000) was the only reference found describing a simple Markov chain model that estimates discount rates based on their occurrence and the probabilities of changes in values over time.

GAO (2014) publication highlighted situations in the US and Europe where the discount rate has its value or its methodology determined by the legislation, and situations where DB plans that use assumed-return are characterized by being sponsored by long-lived companies, resilient to the financial market fluctuations, or federative entities, which can collect more taxes, raising the levels of contribution to the plans. Experts consulted by GAO advised reporting multiple estimates of actuarial liabilities, with different discount rates, minimizing trade-offs between the previous objectives and their implications. The experts also consider that estimating mathematical provisions for the average costs of the plan's benefits based on the allocation of financial assets is the most relevant measure to disclose obligations.

Ribeiro (2015) applied an ALM optimized by stochastic programming for the long term, using primary data of pension plans' financial assets. Dynamic management was adopted for a portfolio composed of Brazilian federal government bonds for three future stages of the economy - expected, average pessimistic, and pessimistic — with different assumptions for the mortality table, ETTJ, contributions, redemption percentages, and conversion into lifetime income. The research showed that the stochastic model obtained returns at least 33\% above those obtained by the deterministic ALM for the initial portfolio.

Pennacchi and Rastad (2011) showed that the US state pension fund managers have agency conflicts in the definition of actuarial rates influenced by their careers, and the presence of the plan's participants on the board contributes to the portfolios reflecting the rates defined in similar pension funds, as opposed to seeking immunization of provisions. Andonov et al. (2017) confirm this last finding when reporting that funds with political board members or members elected among participants are more likely to take a risk and use high values for the actuarial rate.

Sousa and Costa (2015) identified that managers of $\mathrm{DB}$ plans sponsored by state-owned companies or by companies in the financial sector are encouraged to change rates and mortality tables to reduce liabilities, especially when the plan's solvency ratio approaches a deficit. For the authors, EFPCs are compelled, by law, not to be exclusively based on technical-actuarial studies. 
The researched articles described directions to set the actuarial rate. The first direction uses ALM models to combine characteristics of actuarial liabilities with an investment portfolio, aiming to produce an internal rate of return (IRR) representative of the expected return on the plan's assets. Another direction advocates that actuarial rate should be determined based on the estimated returns of a conservative, hypothetical, and hedged portfolio, or low-risk bonds offered in the financial market, with durations similar to those of actuarial liabilities. The last format was not very technical and was influenced by elements such as the composition of the board of trustees, the financial health of the plans, expert opinion, agency conflict, the existence of governmental sponsors or federative entities, and local legislation defining limits and methodologies.

We argue that the MAC proposal put forward in this study, built based on returns originated in an ALM but equally applicable to returns originated in bond-based methodologies, is superior to the proposals and methods described in this reference since MAC offers periodical non-discretionary adjustments of rates defined by the pension fund's board. It considers the differences between the rates of previous years and their corresponding returns on financial assets.

\section{METHODOLOGY}

\section{Panel data model}

This study adopted the panel data and fixed effects models to verify whether the pension funds' actuarial rates are defined by the expected value of the future return on the plan's assets. These models aim to combine cross-section data with time series. Thus, we use these statistical models to identify relationships between the actuarial rate collected in the DA and the other observations of the plans, all varying between 2013 and 2018 and distinctly in each DB plan. Therefore, the different characteristics of the pension plans are considered constituting the non-observable, immutable, or approximately constant effect of each pension fund in the statistical models produced, which minimizes the possible problem of omission of variables that may be relevant in determining the actuarial rate (Fávero, 2013; Hair, Black, Babin, Anderson, \& Tatham, 2009; Marques, 2000; Montgomery, 2017). The data used in the research fit the fixed effects models and variations, one of them indicated in Equation 3, disregarding random and pooled panel data models after statistical tests.

ActuarialRate $_{i, t}=\alpha_{i}+\left(\beta_{1} x_{1, i, t}+\beta_{2} x_{2, i, t}++\beta_{3} x_{3, i, t}+\cdots+\beta_{k} x_{k, i, t}\right)+\varepsilon_{i, t}$

In this equation, the index (i) varies from 1 to 22 and corresponds to the number of DB plans in the research, with ( $t$ ), which varies between 2013 and 2018, corresponding to the respective year when the observations of each plan (i) occurred. ActuarialRate ${ }_{i, t}$ is the model's response variable and refers to the actuarial goal defined in plan (i) in each year $(t)$. The term $\alpha_{i} \sim\left(0, \sigma_{\alpha}^{2}\right)$ is the characteristic, non-observable effect of each plan $i$, corresponding to the intercept, characterizing the planspecific effects constant over time, not captured by the variables $x_{k, i, t}, k=1, \ldots, 14$, and their regressor coefficients $\beta_{k}$, the slope of each explanatory variable in the model. A fixed-effect model assumes that each of the $\beta$ coefficients is the same in the temporal variation of each plan. It is believed that the errors $\varepsilon_{i, t} \sim N\left(0, \sigma_{\varepsilon}^{2}\right)$ are not correlated with each other, and that $\alpha_{i}$ and $x_{k, i, t}$ are correlated.

The term $x_{k, i, t}$ refers to the variables investigated as possible explanations for the response variable. These variables include possible lags, leads (future values), and differences (between the current and previous values), including the response variable itself, resources available in panel data. Table 5 shows the description of the variables $x_{k, i, t}$ used. 
Table 5. Description of the explanatory variables tested in the panel data model.

\begin{tabular}{|c|c|}
\hline Variable & Description \\
\hline Duration & $\begin{array}{l}\text { Corresponds to the duration of the flows that make up the mathematical provisions, calculated by the EFPC based on the } \\
\text { actuarial rate of the previous period }\end{array}$ \\
\hline Return & Shows the real 12-month return on the plan's asset \\
\hline Active members & Number of participants who are active members in the plan \\
\hline Beneficiaries & Number of participants who are receiving benefits in each plan \\
\hline Provisions & The present annual value corresponds to the total future benefits to be paid by each plan \\
\hline Asset & It is the plan's financial asset in the year (for each plan), designated to pay provisions \\
\hline Solvency ratios (SR) & Represents the solvency ratio of each DB plan in the plan each year \\
\hline ParameterrateTMA & $\begin{array}{l}\text { Parameter rate published by the supervisory authority Previc, corresponding to the annual duration of each plan or the discount } \\
\text { rate limit in } 2013\end{array}$ \\
\hline propBoardSpon & The proportion of board members representing the plan's sponsor \\
\hline propBoardPartic & The proportion of board members representing plan's participants \\
\hline Future return & Average of returns on assets calculated in future periods \\
\hline Year & Inserted as a dummy variable to capture effects associated with the year \\
\hline IBOVESPA & $\begin{array}{l}\text { The annual statistics of Ibovespa stock exchange were tested: index values on the first and last business day of the year, } \\
\text { maximum, minimum, and variation in points in the year }\end{array}$ \\
\hline NTN-B & Variables corresponding to the average daily return of NTN-B + IPCA available for purchase and sale in each year were tested \\
\hline
\end{tabular}

Note. This table contains the description of the variables to be tested in the panel data models designed to explain the response variable ActuarialRate.

Data operationalization and processing were based on our experience and the literature mentioned in this section. We emphasize that the variables indicated as NTN-B and Ibovespa sparingly provide the same values in each plan but are different each year. If they were equal in years, their effects would be captured in $\alpha_{i}$.

Although we consider that the MAC method is necessary and complementary to the rules on pension funds, the research will test the hypothesis below described and defended by the aforementioned authors and rooted for years in social security legislation - to secure and justify the proposition put forward in this article.

$\mathrm{H}_{1}$ : Pension funds choose the actuarial rate of a DB plan related to the future return on the financial assets designated to cover the benefits offered.

\section{Consistent actuarial rates (MAC)}

The method proposed in this study considers a five-year adjustment, seeking to mitigate the effects of the distance between actuarial rates determined by the pension fund's board and average returns on investments. This methodology is more efficient than those the pension funds currently adopt because it effectively and cyclically adjusts the actuarial rates chosen by the board to values that include deviations from a past rate for an average performance of the plans' assets. Thus, the amounts corresponding to mathematical provisions will capture the real average performance of financial assets, avoiding administrative and financial management based on undervalued or overestimated provisions for long periods, which creates false impressions of solvency, cooperating, for example, to postpone or anticipate changes in investment portfolios.

The methodology assumes that inflows and outflows of values in financial assets originated from an ALM produce an internal return rate $\theta$ similar to that calculated in Equation 1. The value of this IRR will be the basis for generating MAC. Equation 4 contains the ALM flows in the numerator of the fraction, discounted by factors of $\theta$, resulting in the plan's asset $\rho_{t}$. The value of $t$ refers to the year of the base date where IRR and MAC will be determined.

$$
\frac{\varphi_{t+1}-\tau_{t+1}-\delta_{t+1}}{(1+\theta)^{1}}+\frac{\varphi_{t+2}-\tau_{t+2}-\delta_{t+2}}{(1+\theta)^{2}}+\cdots+\frac{\varphi_{t+y}-\tau_{t+y}-\delta_{t+y}}{(1+\theta)^{\beta}}=\rho_{t}
$$


Variables $\beta$ and $y$ are integers, with $y=1, \ldots, \beta$, and correspond to the deferral in years of the occurrence of each of the flows. The other variables are:

$\varphi_{t+y}$ : the value of benefits paid by the pension plan in each future flow.

$\tau_{t+y}:$ the value of contributions, net of administrative fees or charges, added to the asset in each future flow.

$\delta_{t+y}:$ the value of interest added to the asset in each future flow.

The financial interest values $\left(\delta_{t+y}\right)$ are produced in the ALM study on EFPCs and are originated from the returns on assets. The values of contributions and benefits, $\tau_{t+y} \varphi_{t+y}$, are calculated in each flow by the periodic actuarial valuation and do not depend on any discount rate to be estimated.

The value $\theta$ is the basis for the board to define the actuarial rate, named in the methodology as $\theta^{\prime}$. For this interest rate to become consistent, refined by deviations from past rates, it is necessary that, at the end of year $t$, the average profitability $(\mu)$ of the plan's equity over the last five years, including the current one, and the actuarial rate $(\Phi)$ stipulated on the previous base date to the period of $\mu$. $\epsilon$ would be a value that will adjust $\theta^{\prime}$ and determine the deviation between the five-year returns on assets and the actuarial rate. It is expressed by:

$$
\epsilon=\frac{\mu}{\Phi}
$$

If $\epsilon>1$, the average return $(\mu)$ exceeds the actuarial rate $(\Phi)$ defined for the period, which proved undervaluation. For $\epsilon>1$ the situation is the opposite; the return was below the rate $(\Phi)$ which was overvalued in its definition five years ago. After that, it will be possible to adjust $\theta^{\prime}$ from the discrepancies observed in the last five years. Therefore, the consistent actuarial target $\hat{\theta}$ will be calculated by applying the ratio $\epsilon$ in $\theta^{\prime}$.

$\hat{\theta}=\theta^{\prime} * \epsilon$, for $\epsilon>0$

The $\epsilon$ ratio is a real number, so it is necessary to equalize the results of possible reductions or increases in the rate, avoiding incoherent values that could even make the continuity of the plan unfeasible. An efficient and straightforward way to do this lies in rules that use lower and upper limits based on a reasonable percentage of variability for $\theta^{\prime}$. We used the following rules in the research:

1. If $\hat{\theta}$ belongs to $\left[0,777 \cdot \theta^{\prime} ; 1,280 \cdot \theta^{\prime}\right]$, the plan's real interest rate will be MAC calculated in (6).

2. If $\hat{\theta}<0,777 \cdot \theta^{\prime}$ then $\hat{\theta}=0,777 \cdot \theta^{\prime}$.

3. If $\hat{\theta}>1,280 \cdot \theta^{\prime}$ then $\hat{\theta}=1,280 \cdot \theta^{\prime}$.

4. MAC cannot assume values below the average return of government bonds due +5 years onward, available during year $t$.

The last rule is justified because we consider that a minimal effort by the EFPC's investment management would allow the reallocation, during year $t$, of a large part of the portfolio for maximum exposure to government bonds.

The values of 0.777 and 1.280 were found in the 22 plans of the sample. They refer to the medians of the $\epsilon$ for two groups of plans. The value 0.777 refers to the group formed by plans with average returns below the rates $(\Phi)$ determined in 2013, while 1.280 refers to the group of plans where each average $(\mu)$ exceeded the rate defined individually in 2013. In both cases, the period observed was 2014 to 2018 . These medians should be appropriately evaluated, reflecting the reality of management and better management of asset portfolios.

Thus, five-year moving average is used, in which each year will be integrated to the value of $\epsilon$ to achieve a consistent rate, sufficient to remedy part or all of the deviations between real and expected returns on assets. We emphasize the importance of using adequacy tests to verify the adherence of the rate obtained by adopting the MAC method to the average profitability calculated from the following year, monitoring the method's efficiency.

\section{ANALYSIS OF RESULTS}

\section{Models found}

Panel data modeling applied to the original information of the 22 DB plans, based on Equation 3, produced a model, the base model (Table 6). 
Table 6. Explanatory variables of the fixed effects base model.

\begin{tabular}{|c|c|c|c|c|}
\hline \multicolumn{5}{|c|}{ Response variable: ActuarialRate } \\
\hline Explanatory variables & Regression coefficient & Standard error & \multicolumn{2}{|l|}{$\operatorname{Pr}(>|t|)$} \\
\hline Provisions & $1.25 \mathrm{e}-13$ & $1.84 \mathrm{e}-13$ & \multicolumn{2}{|l|}{0.498} \\
\hline Assets & $-2.55 e-14$ & $2.08 \mathrm{e}-13$ & \multicolumn{2}{|l|}{0.903} \\
\hline SR & 0.0189 & 0.008 & \multicolumn{2}{|l|}{$0.026 *$} \\
\hline ParameterrateTMA & 0.6871 & 1.0259 & \multicolumn{2}{|l|}{0.505} \\
\hline Duration & 0.0002 & 0.0003 & \multicolumn{2}{|l|}{0.641} \\
\hline ActiveMembers & $-6.56 e-07$ & $1.0305 \mathrm{e}-06$ & \multicolumn{2}{|l|}{0.526} \\
\hline NumberBeneficiaries & $-1.12 e-06$ & $1.0592 \mathrm{e}-06$ & \multicolumn{2}{|l|}{0.294} \\
\hline Return & -0.0252 & 0.0123 & \multicolumn{2}{|l|}{$0.043^{*}$} \\
\hline propBoardSpons & -0.0102 & 0.0099 & \multicolumn{2}{|l|}{0.307} \\
\hline Year2014 & -0.0057 & 0.0061 & \multicolumn{2}{|l|}{0.356} \\
\hline Year2015 & -0.0074 & 0.0054 & \multicolumn{2}{|l|}{0.174} \\
\hline Year2016 & -0.005 & 0.0050 & \multicolumn{2}{|l|}{0.320} \\
\hline Year2017 & -0.0036 & 0.0057 & \multicolumn{2}{|l|}{0.533} \\
\hline Year2018 & -0.0026 & 0.0033 & \multicolumn{2}{|l|}{0.436} \\
\hline FutRetAsset & -0.0186 & 0.0239 & \multicolumn{2}{|l|}{0.437} \\
\hline Model's F-statistic: & 2.6404 (p-value: 0.004$)^{* *}$ & & $R^{2}:$ & 0.2942 \\
\hline Residual statistics & \multicolumn{4}{|c|}{-0.0273 (minimum); -0.0014 (1st Q); -0.00001 (median); 0.0017 (3rd Q); 0.014 (maximum) } \\
\hline \multicolumn{4}{|c|}{ Breusch-Pagan test: $\mathrm{H} 0$ for homoscedasticity of residuals } & 0.21 \\
\hline \multicolumn{4}{|c|}{ Breusch-Godfrey/Wooldridge test: H0 for non-serial correlation of residuals } & $0.000 * * *$ \\
\hline \multicolumn{4}{|c|}{ Shapiro-Wilk test: $\mathrm{H} 0$ to residual normality } & $0.000^{* * *}$ \\
\hline
\end{tabular}

Note. This table contains information from the base model of fixed effects for the response variable ActuarialRate, produced by the statistical package R. FutRetAsset represents the average return on assets in the following years of the sample. The variables related to years are dummies of control to check the influence of the period on the response variable. The other variables are described in Table 5 . The regression coefficients correspond to $\beta_{k}$ of Equation 3 followed by its standard error. The last column refers to the $\mathrm{p}$-value that tests the null-regression-coefficient hypothesis (t-Student statistics were omitted), followed by the representation of significance: $\cdot,{ }^{*},{ }^{* *}$ and ${ }^{* * *}$, respectively, $10 \%$, $5 \%, 1 \%$, and $0.1 \%$. F statistic tests the hypothesis that the model's coefficients are null, so it is inconsistent and $R^{2}$ is null, rejected if its p-value is less than 0.05 .

The panel base model applied to the original base values presented the significant variables $S R$ and returns in the definition of the response variable ActuarialRate, a reasonable $R^{2}$, coefficient of determination, and explaining almost $29 \%$ of the rate's variance. The Breusch-Pagan test (Breusch \& Pagan, 1979) indicated homoscedasticity of the residual, which has a null mean and constant variance. However, the Shapiro-Wilk (Razali \& Wah, 2011) and Breusch-Godfrey/Wooldridge (Croissant \& Millo, 2008; Torres-Reyna, 2010) tests rejected normality and found a serial correlation in the residuals, affecting the reliability of $\mathrm{p}$-values and the $\mathrm{F}$ test of the model, causing underestimated variances due to possible autocorrelations between the values of the variables for the previous or more distant period. Therefore, the base model was not robust.

The previous results and the analysis of possible solutions for data transformation to allow a vigorous model resulted in the choice of a variation of the fixed effects model (Equation 3) - after we suspected that the intercept $\alpha i$ would be biased, exhibiting similar values among pension funds, with the same signal. We found a solution in the literature to replace $\alpha i$ to obtain a general effect in the model (an average value) representing the joined effects of all funds. Thus, we changed Equation 3 , adding the intercept $\alpha$ to the response variable MetaAtuarial $_{i, t}$ and to the intercept $\alpha_{i}$, rewriting it in Equation 7.

ActuarialRate $_{i, t}=\alpha+\left(\beta_{1} x_{1, i, t}+\beta_{2} x_{2, i, t}++\beta_{3} x_{3, i, t}+\cdots+\beta_{k} x_{k, i, t}\right)+\left(\alpha_{i}-\alpha+\varepsilon_{i, t}\right)$

This variation is known as the between fixed effects estimator, consisting of a model that explains the averages of the response variables through the average of the explanatory variables (Croissant \& Millo, 2008; 
Duarte, Lamounier, \& Takamatsu, 2007; Fávero, 2013). The new error should not be correlated to the significant explanatory variables that will belong to the model. Table 7 contains the information from the model produced by the fixed effects between estimator after inserting and removing variables (previously evaluated by correlations) from the model, similar to the stepwise method (Hair et al., 2009; Montgomery, 2017). The model and its variables are the inputs to confirm or refute hypothesis $\mathrm{H}_{1}$, that states that the actuarial rate defined in pension funds represents the future return on its associated $\mathrm{DB}$ plan's asset.

Table 7. Explanatory variables and tests of the fixed effects between model.

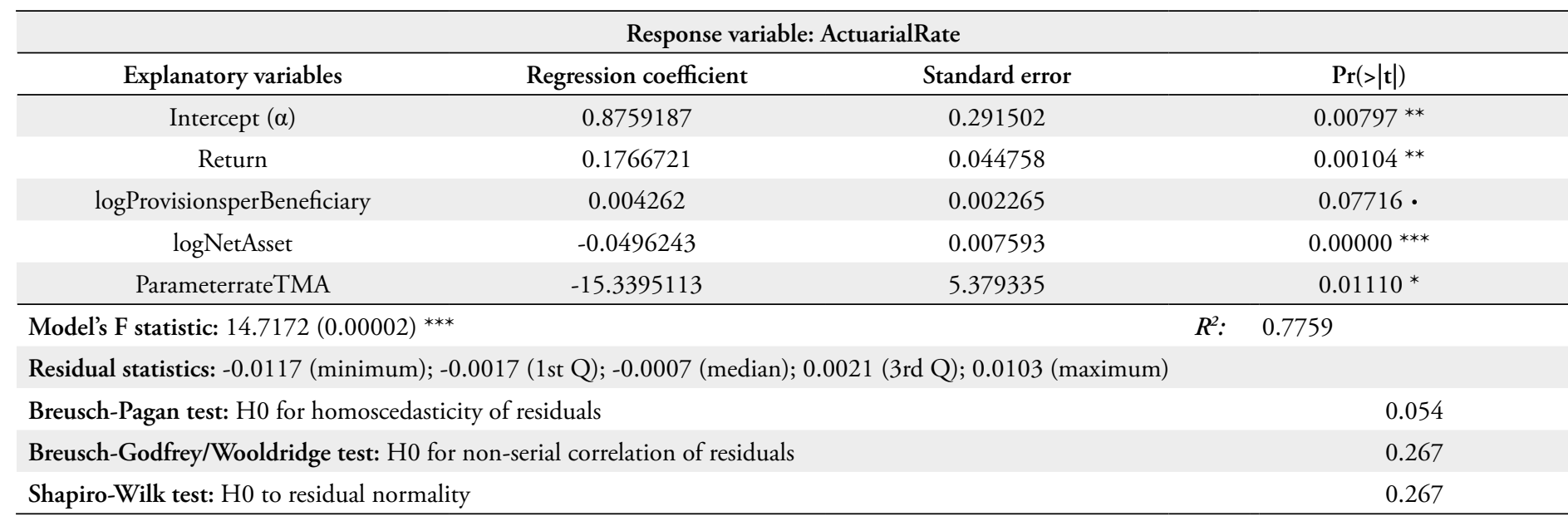

Note. This table contains the information of the model that explains the response variable ActuarialRate, applied to the values during six years in data collected from $22 \mathrm{DB}$ plans. The LogProvisionsperBeneficiaries variable refers to using the logarithmic transformation in the calculated amounts of provisions per beneficiary assisted by the DB plan. The variable logNetAsset corresponds to the difference between the natural logarithm of the asset and the natural logarithm of provisions.

This model has a good coefficient of determination (77.6\%), sufficient for the explanatory rather than the predictive purpose of the model, to clarify the elements that determined past values of the actuarial rate, explaining almost $80 \%$ of the actuarial rate's variance. In addition to the good $R^{2}$, the $\mathrm{F}$ statistic supports the regressor coefficients, confirmed by statistical tests that showed that the residuals are homoscedastic, present normality, and do not show serial correlation. Therefore, the following representation of the model with statistically significant coefficients becomes viable:

ActuarialRate $_{i, t}=0.87592+0.17667 \cdot$ Return $_{i, t}$

$$
\begin{gathered}
+0.00426 \cdot \log \left(\frac{\text { Provisions }_{i, t}}{\text { NumberBeneficiaries }_{i, t}}\right) \\
-0.04962 \cdot\left[\log \left(\text { Asset }_{i, t}\right)-\log \left(\text { Provisions }_{i, t}\right)\right] \\
-15.3395 \cdot \text { ParameterrateTM }_{i, t}+u_{i, t} ; \\
\text { where } u_{i, t}=\left(\alpha_{i}-0.87592+\varepsilon_{i, t}\right)
\end{gathered}
$$

The model described in Equation 8 is sufficient to confront hypothesis $\mathrm{H}_{1}$. It has an intercept that constitutes the representative general effect of each pension fund. Its coefficient is significant at a level of $1 \%$ and explains, positively, part of the actuarial rate defined in EFPCs. The return is another variable that positively influences the rate, corresponding to the individual performance of the asset in each period of the series. It presents the same significance as the intercept. Parameterrate TMA, which reduces the rate and corresponds to the parameter rate associated with the specific duration of the DB plan, or the actuarial rate limit in 2013, has a significance level of $5 \%$. The variable $\operatorname{logNetAsset}$ is the most significant in the model (its level is $0.1 \%$ ). However, its negative coefficient can positively or negatively influence the rate, depending on the value of the difference between the asset logarithm and provisions logarithm. If it is a deficit, or asset smaller than the provisions, the influence will be positive; if it is a surplus, it will be a negative influence. The last variable, logProvisionsperBeneficiaries, was represented as the logarithm of the division of provisions by the number of beneficiaries in each plan. Its significance level is $10 \%$ (acceptable limit) and positively affects the actuarial rate.

Therefore, the best model found (Equation 8) allows us to infer that the response variable ActuarialRate 
is influenced by the very short-term past returns (last 12 months), the parameter rate (limit rate) available in the year, by the annual level of provision per beneficiary, the current result of the plan (the net asset, deficit or surplus), and the idiosyncratic effect that we attribute to the characteristic effect of the EFPCs sector, the pension funds. These inferences allow us to reject hypothesis $\mathrm{H}_{1}$ since the actuarial rate does not represent any variable wholly or partially associated with the returns of each DB plan.

In our view, the rejection of $\mathrm{H}_{1}$ justifies the MAC proposition. Additionally, the evidence that the actuarial rate does not capture future returns contradicts Bertucci et al. (2006), Silva et al. (2007), Corrêa (2018), Vittas (2010) and Andonov et al. (2017). It also distorts Resolution 30, which stipulates, as a general rule, the association between rate and returns. To a lesser degree, this dissociation from returns affects the composition of ALM defended by Haneveld, Streutker and Van Der Vlerk (2010) and the effort made by Leal and Mendes (2010) to demonstrate multimarket strategies that meet the actuarial rate.

On the other hand, the presence of the parameter rate in the model confirms that pension funds are chosen, included in Resolution 30, for actuarial rates based on past ETTJ averages, which are almost 10 months away from the base date of the actuarial calculations. We understand that this fact corroborates Bicalho (2018), who identified that the performance of the EFPC's asset was similar to the benchmark CDI rate. However, we cannot say that the presence of the parameter rate in the model means that the actuarial rate represents prospective returns of the rates observed in low-risk bonds, as reported in Chapman et al. (2001), Bader and Gold (2003), Varga (2009), Caldeira (2011), GAO (2014), Duarte et al. (2015), Silva et al. (2015) and Novy-Marx (2015). The presence of the net asset in the model shows a partial influence by the solvency ratio, as advocated by Sousa and Costa (2015) in the case of deficits.

Corroborating Pennacchi and Rastad (2011) and Andonov et al. (2017), we did not find indicators of the influence of board composition in the definition of the actuarial rate.

\section{Application of the consistent actuarial rate (MAC) in the research data}

The data collected from the $22 \mathrm{DB}$ plans made it possible to apply the MAC as defined in subsection 4.2. It was possible to refine the actuarial rate chosen in 2018, using the five-year return from 2014 to 2018 to find the ratio between this average and the last valid actuarial rate in 2013. This ratio was applied to the rate chosen by the board in 2018, which generated a new value for the actuarial rate for the period, observing the lower and upper limits calculated in the research sample and the average returns of NTN-B due in 2024, 2035, 2045, and 2050.

Table 8 shows the steps for applying MAC in the plans and values produced for the 2018 rate. The average of actuarial rates went from $5.36 \%$, values determined by the board in 2018, to $6.09 \%$, after MAC, an increase of $0.73 \%$. The method worked efficiently with the information presented, comprising the rule that sustains reductions in the rate for values lower than the average return of NTN-B (4.94\% p.a. in 2018). Similarly, very high values were limited, avoiding rates that represented returns difficult to maintain in the long term.

Banco do Brasil (2018) estimated a 2.2\% reduction in the actuarial obligation if the actuarial rate of $5.3 \%$ p.a. changed to $5.55 \%$. Due to the proximity to the $5.36 \%$ average of the sample's actuarial rate, we used this sensitivity to estimate that the provision of BRL 365 billion, mentioned in subsection 2.3, when associated with the $5.36 \%$ average, would be revalued to BRL 341.6 billion. This retraction of BRL 23.4 billion, or almost BRL 1.1 billion per plan, would result in immediate economic effects, such as reducing the regular costing rates and revaluating extraordinary costs.

We believe that participants and sponsors would be the principal beneficiaries of applying the adjustments on the actuarial rate of the plans in the sample, which would allow adequate levels of contribution, equivalent to the promised benefits. It would also benefit the pension funds, which would present financial situations consistent with their returns, favoring the acquisition of insurance to cover social security risks, with premiums that reflect the presence of the MAC method in the insurance companies' risk assessment. 
Table 8. Application of the consistent actuarial rate (MAC) method to define the actuarial rate in 2018.

\begin{tabular}{|c|c|c|c|c|c|c|c|c|c|}
\hline EFPC plan & $\begin{array}{c}\text { Rate } 2018 \\
\left(\theta^{\prime}\right)\end{array}$ & $\begin{array}{c}\text { Return } \\
2014- \\
2018(\mu)\end{array}$ & $\begin{array}{l}\text { Rate } 2013 \\
\quad(\Phi)\end{array}$ & $\varepsilon$ & $\begin{array}{c}\text { Previous } \\
\text { value }(\hat{\theta})\end{array}$ & $\begin{array}{c}\text { Lower } \\
\text { limit } \\
\left(0,777 \cdot \theta^{\prime}\right)\end{array}$ & $\begin{array}{c}\text { Upper } \\
\text { limit } \\
\left(1,280 \cdot \theta^{\prime}\right)\end{array}$ & $\begin{array}{c}\text { MAC } \\
(\hat{\theta})\end{array}$ & $\begin{array}{l}\text { MAC } \\
\text { effect }\end{array}$ \\
\hline PBB - Centrus & $4.50 \%$ & $4.52 \%$ & $4.00 \%$ & 1.13 & $5.09 \%$ & $3.50 \%$ & $5.76 \%$ & $5.09 \%$ & 1 \\
\hline PBDC - Centrus & $4.50 \%$ & $4.99 \%$ & $4.00 \%$ & 1.25 & $5.62 \%$ & $3.50 \%$ & $5.76 \%$ & $5.62 \%$ & $\uparrow$ \\
\hline BD - Fachesf & $5.50 \%$ & $6.24 \%$ & $5.75 \%$ & 1.09 & $5.97 \%$ & $4.27 \%$ & $7.04 \%$ & $5.97 \%$ & 1 \\
\hline RegReplan - Funcef & $4.50 \%$ & $1.43 \%$ & $5.50 \%$ & 0.26 & $1.17 \%$ & $3.50 \%$ & $5.76 \%$ & $4.94 \%$ & 1 \\
\hline PPSP - Petros & $5.27 \%$ & $-0.15 \%$ & $5.50 \%$ & -0.03 & $-0.14 \%$ & $4.09 \%$ & $6.75 \%$ & $4.94 \%$ & $\downarrow$ \\
\hline PB1 - Previ & $5.00 \%$ & $3.84 \%$ & $5.00 \%$ & 0.77 & $3.84 \%$ & $3.88 \%$ & $6.40 \%$ & $4.94 \%$ & $\mathcal{G}$ \\
\hline Plano BD-Real - Grandeza & $5.60 \%$ & $7.22 \%$ & $5.50 \%$ & 1.31 & $7.35 \%$ & $4.35 \%$ & $7.17 \%$ & $7.17 \%$ & 1 \\
\hline Plano A - Forluz & $6.00 \%$ & $4.52 \%$ & $5.75 \%$ & 0.79 & $4.72 \%$ & $4.66 \%$ & $7.68 \%$ & $4.94 \%$ & $\downarrow$ \\
\hline $\begin{array}{l}\text { Plano Unificado BD - } \\
\text { Fundaçáo Copel }\end{array}$ & $5.80 \%$ & $6.69 \%$ & $5.75 \%$ & 1.163 & $6.74 \%$ & $4.51 \%$ & $7.43 \%$ & $6.74 \%$ & 1 \\
\hline Plano II - Banesprev & $6.88 \%$ & $7.20 \%$ & $6.00 \%$ & 1.2 & $8.25 \%$ & $5.35 \%$ & $8.81 \%$ & $8.25 \%$ & $\hat{1}$ \\
\hline Plano V - Banesprev & $10.16 \%$ & $11.19 \%$ & $5.75 \%$ & 1.946 & $19.77 \%$ & $7.89 \%$ & $13.01 \%$ & $13.01 \%$ & $\uparrow$ \\
\hline Plano A/B - Braslight & $5.00 \%$ & $6.09 \%$ & $5.75 \%$ & 1.059 & $5.29 \%$ & $3.88 \%$ & $6.40 \%$ & $5.29 \%$ & 1 \\
\hline Único da CEEE - Eletroceee & $5.61 \%$ & $5.15 \%$ & $5.50 \%$ & 0.936 & $5.25 \%$ & $4.36 \%$ & $7.18 \%$ & $5.25 \%$ & $\downarrow$ \\
\hline $\begin{array}{l}\text { PSAP - Eletropaulo - } \\
\text { Funcesp }\end{array}$ & $5.64 \%$ & $7.43 \%$ & $5.50 \%$ & 1.351 & $7.62 \%$ & $4.38 \%$ & $7.22 \%$ & $7.22 \%$ & $\hat{1}$ \\
\hline PBS-A - Sistel & $4.19 \%$ & $5.34 \%$ & $3.80 \%$ & 1.406 & $5.89 \%$ & $3.26 \%$ & $5.37 \%$ & $5.37 \%$ & 1 \\
\hline PBD - Telos & $4.50 \%$ & $6.06 \%$ & $4.50 \%$ & 1.347 & $6.06 \%$ & $3.50 \%$ & $5.76 \%$ & $5.76 \%$ & $\uparrow$ \\
\hline PCV I - Telos & $4.50 \%$ & $7.52 \%$ & $4.50 \%$ & 1.671 & $7.52 \%$ & $3.50 \%$ & $5.76 \%$ & $5.76 \%$ & $\uparrow$ \\
\hline $\begin{array}{l}\text { PAC - Fundação Itaú- } \\
\text { Unibanco }\end{array}$ & $4.19 \%$ & $5.92 \%$ & $4.00 \%$ & 1.480 & $6.20 \%$ & $3.26 \%$ & $5.37 \%$ & $5.37 \%$ & $\widehat{1}$ \\
\hline PB1 - Usiminas & $5.50 \%$ & $4.94 \%$ & $4.50 \%$ & 1.098 & $6.04 \%$ & $4.27 \%$ & $7.04 \%$ & $6.04 \%$ & $\uparrow$ \\
\hline Benefício Definido - Valia & $5.00 \%$ & $4.78 \%$ & $4.75 \%$ & 1.005 & $5.03 \%$ & $3.88 \%$ & $6.40 \%$ & $5.03 \%$ & U \\
\hline Funbep I - Funbep & $5.70 \%$ & $5.48 \%$ & $5.50 \%$ & 0.997 & $5.68 \%$ & $4.43 \%$ & $7.30 \%$ & $5.68 \%$ & O \\
\hline Plano A - Previrb & $4.38 \%$ & $8.01 \%$ & $4.00 \%$ & 2.004 & $8.78 \%$ & $3.40 \%$ & $5.61 \%$ & $5.61 \%$ & $\hat{1}$ \\
\hline
\end{tabular}

Note. This table shows the application of the MAC method to the plans' data. The variables of the columns are defined in subsection 4.2. The last column represents the MAC effect: the up arrow indicates that MAC raised the 2018 rate. The down arrow indicates a reduction. The circle represents that the 2018 rate remained practically unchanged after applying MAC. NTN-B IPCA+ due in 2050, 2045, 2035, and 2024 were available in the government bond market in 2018, with their annual averages showing a minimum return of $4.94 \%$.

\section{CONCLUSIONS}

We believe that the conditions offered for using the parameter rate, compared to the general rule, may inhibit a more significant performance when seeking returns on pension fund investments. This inhibition happens because the rule allows choosing a rate belonging to the interval of a parameter rate to the detriment of the expected return on the plan's equity and requires a technical report for rates outside this interval.

This study identified that the choice of the actuarial rate in the sample analyzed was influenced by the annual return on pension assets, based on the net asset observed on the base date and on the parameter rate itself, which represents past returns according to ETTJ. The constructed 
statistical models found no evidence of adherence between the actuarial rate defined by the fund's board and the future return on the plan's assets. Also, it was not possible to detect the influence of government bonds regarding a contribution from the due NTN-B return rates in the actuarial rate. Therefore, actuarial rates set in the sample plans are not related to the assumed-return or bond-based methodologies described in GAO (2014). These indications justify a different approach to the definition of the actuarial rate, represented in this article by the meta atuarial consistente (MAC) (consistent actuarial rate).

We believe that using the MAC method will contribute to the evolution of rules and techniques that support actuarial rate choices in pension funds. MAC allows for possible biases between a past target and the five-year return on assets to be considered and incorporated into the model, refining and offering a greater expectation of accuracy to the value chosen by the board of trustees for the actuarial rate and, over the years, converging this rate to the average return on the plan's assets.

As for the limitations of this research, we did not have sufficient resources and time to collect information from more DB plans from the content located in the DA actuarial statements from 2018 submitted to the supervisory authority Previc, released for access only in 2020, during the preparation of this study.

In turn, MAC presents limitations regarding the lower and upper limits calculated with data from the research sample. In addition, one of the lower limits is based on the 2018 average NTN-B rates. However, it could be broader, incorporating other available low-risk bonds or even a minimum return guaranteed by insurance companies. These minor obstacles can be diminished and even resolved

\section{REFERENCES}

Alda, M. (2018). A strategic fund family business decision: The pension fund liquidation. Journal of Business Research, 91, 248-265. https://doi.org/10.1016/j.jbusres.2018.06.024

Andonov, A., Bauer, R. M., \& Cremers, K. J. M. (2017). Pension fund asset allocation and liability discount rates. The Review of Financial Studies, 30(8), 2555-2595. https://doi.org/10.1093/rfs/hhx020

Associação Brasileira das Entidades dos Mercados Financeiro e de Capitais. (2017). Estrutura a termo da taxa de juros intradiária $12 \mathrm{~h}$ - metodologia. Retrieved from https://www.anbima.com.br/data/files/F9/73/38/F5/ C2DEA510CD3B4DA568A80AC2/ETTJ-IntraMetodologia.pdf if regulatory and supervisory authorities, especially Previc, adopt the proposed methodology. Thus, it will be possible to use the population parameters of all plans of EFPCs, setting new limits for MAC and making the proposed method a market standard, allowing any DB plan to apply MAC and adjust its actuarial rate.

As for best practices of governance, official documents of the entities may include MAC and the actuarial rate the board chose and established. This measure offers transparency to this issue, allowing future comparisons between the plan's actuarial rate (set by the board), the consistent actuarial interest rate (proposed here), and the return actually obtained in the period.

The research findings suggest the need for future studies to investigate, at least, the composition of the boards of trustees (conselhos deliberativos) in a larger sample of pension funds, covering a more extended period. Interviews with participants of these boards would be helpful to analyze the decision-making processes and the content of minutes of the plenary sessions, observing the choices regarding investment allocation or actuarial and economic assumptions. The results of such research would contribute to identify the pension funds' dynamics, evaluating them in contexts of the pension market's governance and compliance.

Taking advantage of the MAC method will allow pension funds to more effectively review and adjust their costing plans, particularly their contribution rate values, deficits, and surpluses. The application of this research's findings can lead to greater efficiency in the Brazilian closed pension fund market, contributing to the sustainability and solidity of the system, with positive consequences for the country's economic growth.
Associação Brasileira das Entidades Fechadas de Previdência Complementar. (2018). Consolidado estatístico dezembro 2018. Retrieved from https://www.abrapp. org.br/wp-content/uploads/2020/09/ConsolidadoEstati\%CC\%81stico 12.2018.pdf

Associação Brasileira das Entidades Fechadas de Previdência Complementar. (2019). Consolidado estatístico dezembro 2019. Retrieved from https://www.abrapp. org.br/wp-content/uploads/2020/09/ConsolidadoEstati\%CC\%81stico 12 2019.pdf

Attilio, L.A. (2020). A Influência da financeirização sobre a taxa de juros real brasileira. Revista de Economia Contemporânea, 24(3), e202431. https://doi.org/10.1590/198055272431 
Azambuja, S., \& Campani, C. H. (2019). Impactos da reforma da previdência nos déficits dos planos de contribuição variável. Revista de Gestão, Finanças e Contabilidade, 9(3). https://doi.org/10.18028/rgfc.v9i3.7255

Bader, L. N. \& Gold, J. (2003). Reinventing pension actuarial science. The Pension Forum, 15(1), 1-13. Retrieved from http://users. erols.com/jeremygold/reinventingpensionactuarialscience. pdf

Banco do Brasil. (2018). Análise do desempenho $1^{\circ}$ trimestre 2018 [Report]. Retrieved from https://www.bb.com.br/docs/pub/ siteEsp/ri/pt/dce/dwn/1T18AnaliseDesempCI.pdf

Bertucci, L. A., Souza, F. H. R., \& Félix, L. F. F. (2006). Gerenciamento de risco de fundos de pensão no Brasil: Alocação estratégica ou simples foco na meta atuarial? Revista Economia \& Gestão, 6(13). Retrieved from http://periodicos.pucminas.br/index. php/economiaegestao/article/view/25

Bicalho, F. C. (2018). Avaliação dos investimentos dos fundos de previdência complementar do Brasil (Master's thesis). Universidade Católica de Brasília, Escola de Gestão e Negócios, Brasília, DF, Brazil. Retrieved from https://bdtd.ucb.br:8443/jspui/bitstream/ tede/2410/2/FilipeCarneiroBicalhoDissertacao2018.pdf

Binswanger, J., \& Schunk, D. (2012). What is an adequate standard of living during retirement? Journal of Pension Economics o Finance, 11(2), 203-222. https://doi.org/10.1017/ $\underline{\mathrm{S} 1474747211000618}$

Breusch, T. S., \& Pagan, A. R. (1979). A simple test for heteroscedasticity and random coefficient variation. Econometrica, 47(5), 1287 1294. https://doi.org/10.2307/1911963

Caldeira, J. F. (2011). Estimação da estrutura a termo da curva de juros no Brasil através de modelos paramétricos e não paramétricos. Revista Análise Econômica, 29(55), 95-122. https://doi.org/10.22456/2176-5456.13198

Chapman, R. J., Gordon, T. J., \& Speed, C. A. (2001). Pensions, funding and risk. British Actuarial Journal, 7(4), 605-662. https://doi.org/10.1017/S1357321700002488

Corrêa, R. B. (2018). Modelo de simulação de governança de passivo atuarial de um fundo de pensão brasileiro (Master's thesis). Universidade Federal do Rio Grande do Sul, Escola de Administração, Porto Alegre, RS, Brazil. Retrieved from http://hdl.handle.net/10183/180828

Croissant, Y., \& Millo, G. (2008). Panel data econometrics in R: The plm package. Journal of Statistical Software, 27(2), 1-43. https://doi.org/10.18637/jss.v027.i02

De La Peña, J. I., Garayeta, A., \& Iturricastillo, I. (2017). Dynamic immunisation does not imply cash flow matching: A hard application to Spain. Economic Research-Ekonomska istraživanja, 30(1), 238-255. https://doi.org/10.1080/1331677X.2017.1305780

Duarte, A. A., Silva, A. F., Oliveira, L. V., Weffort, E. F. J., \& Chan, B. L. (2015). The term structure of interest rates and its impact on the liability adequacy test for insurance companies in Brazil. Revista Contabilidade \& Finanças, 26(68), 223-236. https://doi.org/10.1590/1808-057x201500420
Duarte, P. C., Lamounier, W. M., \& Takamatsu, R. T. (2007). Modelos econométricos para dados em painel: Aspectos teóricos e exemplos de aplicação à pesquisa em contabilidade e finanças. Anais do Congresso USP de Iniciação Científica em Contabilidade (Vol. 4, pp. 1-15). Retrieved from https:// edisciplinas.usp.br/pluginfile.php/176819/mod resource/ content/1/Artigo\%20-\%20Modelos\%20em\%20Painel.pdf

Fávero, L. P. L. (2013). Dados em painel em contabilidade e finanças: Teoria e aplicaçáo. Brazilian Business Review, 10(1), 131-156. Retrieved from https://www.redalyc.org/pdf/1230/123025719006.pdf

Giambiagi, F., \& Afonso, L. E. (2009). Cálculo da alíquota de contribuição previdenciária atuarialmente equilibrada: Uma aplicação ao caso brasileiro. Revista Brasileira de Economia, 63(2), 153-179. https://doi.org/10.1590/S0034-71402009000200006

Government Accountability Office. (2014, September). Pension plan valuation: Views on using multiple measures to offer a more complete picture [Report GAO-14-264]. Retrieved from http://www.gao.gov/assets/670/666287.pdf

Haneveld, W. K. K., Streutker, M. H., \& Van Der Vlerk, M. H. (2010). An ALM model for pension funds using integrated chance constraints. Annals of Operations Research, 177, 47-62. https://doi.org/10.1007\%2Fs10479-009-0594-4

Hansen, M., \& Miltersen, K. R. (2002). Minimum rate of return guarantees: The Danish case. Scandinavian Actuarial Journal, 2002(4), 280-318. https://doi.org/10.1080/03461230110106282

Hair, J. F., Black, W. C., Babin, B. J., Anderson, R. E., \& Tatham, R. L. (2009). Análise multivariada de dados. Porto Alegre: Editora Bookman.

Kimura, R. Y. (2019). Definição dos limites da premissa de taxa de retorno real para planos de previdência complementar utilizando o modelo HJM (Master's thesis). Fundação Getulio Vargas, EESP, São Paulo, SP, Brazil. Retrieved from http://hdl.handle.net/10438/28040

Leal, R. P. C., \& Mendes, B. V. M. (2010). The risk-return relationship of pension funds with investments in hedge funds. Latin American Business Review, 11(2), 141169. https://doi.org/10.1080/10978526.2010.496307

Levy, S. (2011). Pensions in the national accounts: Compiling a complete picture of UK pensions including unfunded pensions for public sector employees. Economic \& Labour Market Review, 5, 87-112. https://doi.org/10.1057/elmr.2011.71

Libânio, G. (2010). A note on inflation targeting and economic growth in Brazil. Brazilian Journal of Political Economy, 30(1), 73-88. https://doi.org/10.1590/S0101-31572010000100005

Lima, A. C. (2006). Desempenho dos fundos de investimento do tipo previdência privada e sua sensibilidade à variaçáo da taxa de juros. RAM. Revista de Administraçâo Mackenzie, 7(2), 6177. https://doi.org/10.1590/1678-69712006/administracao. v7n2p61-77

Marques, L. D. (2000, October). Modelos dinâmicos com dados em painel: Revisão de literatura [Working Paper n. 100]. Universidade do Porto, Faculdade de Economia do Porto, Centro de Estudos Macroeconômicos e Previsão, Porto, Portugal. Retrieved from http://wps.fep.up.pt/wps/wp100.pdf 
Martins-Costa, J. (2005). Reflexôes sobre o princípio da função social dos contratos. Revista Direito GV,1(1), 41-66. Retrieved from http://bibliotecadigital.fgv.br/ojs/index.php/revdireitogv/ article/view/35261

Mesa-Lago, C. (2006). Private and public pension systems compared: An evaluation of the Latin American experience. Review of Political Economy, 18(3), 317-334. https://doi.org/10.1080/09538250600797768

Montgomery, D. C. (2017). Design and analysis of experiments. New York: John Wiley \& Sons.

Motta, L. F. J., \& Santoro, R. M. (2003). Desempenho dos fundos de pensão fechados no Brasil: Uma análise comparativa com planos geradores de benefícios livres (PGBL's). Revista de Economia e Administração, 2(2), 87-102. Retrieved from http://www.spell.org.br/documentos/ver/25636/ desempenho-dos-fundos-de-pensao-fechados-no-brasil-uma-analise-comparativa-com-planos-geradores-debeneficios-livres--pgbl---s-/i/pt-br

Nese, A. A. S. (2017). Governança, características das organizaçôes $e$ desempenho dos investimentos: Evidências em fundos de pensáo no Brasil (Doctoral dissertation). Universidade de Sáo Paulo, Faculdade de Economia, Administração e Contabilidade, São Paulo, SP, Brazil. https://doi.org/10.11606/T.12.2017.tde-13062017-162106

Norberg, R. (2000). Basic life insurance mathematics [Lecture notes]. University of Copenhagen, Laboratory of Actuarial Mathematics. Retrieved from https://www.simiode.org/ resources/4080/download/2002-Norberg-Basic_Life_ Insurance_Mathematics.pdf

Novy-Marx, R. (2015). Economic and financial approaches to valuing pensionliabilities.JournalofPensionEconomics \& Finance, 14(2), 144-150. https://doi.org/10.1017/S1474747214000468

Pennacchi, G., \& M. Rastad. (2011). Portfolio allocation for public pension funds. Journal of Pension Economics \& Finance, 10(2), 221-245. https://doi.org/10.1017/S1474747211000102

Pereira, M. M. (2013). Impactos da redução nas taxas de juros da economia para os fundos de pensáo (Master's thesis). Universidade de Brasília, Faculdade de Economia, Administração, Contabilidade e Ciência da Informação e Documentação, Brasília, DF, Brazil. Retrieved from https://repositorio.unb.br/handle/10482/15542

Petrobras (2019). Informaçóes trimestrais - 31/03/2019. Retrieved from https://www.conjur.com.br/dl/provisoes-petrobrasprocessos-ficam.pdf

Razali, N. M., \& Wah, Y. B. (2011). Power comparisons of Shapiro-Wilk, Kolmogorov-Smirnov, Lilliefors and Anderson-Darling tests. Journal of Statistical Modeling and Analytics, 2(1), 21-33. Retrieved from https://www. researchgate.net/profile/Bee_Yap/publication/267205556 Power_Comparisons_of_Shapiro-Wilk_KolmogorovSmirnov_Lilliefors_and_Anderson-Darling_Tests/ links/5477245b0cf29afed61446e1/Power-Comparisonsof-Shapiro-Wilk-Kolmogorov-Smirnov-Lilliefors-andAnderson-Darling-Tests.pdf

Ribeiro, G. X. K. (2015). Asset liability management em um plano aberto de previdência tradicional (Master's thesis). Instituto de Matemática Pura e Aplicada - IMPA, Rio de Janeiro, RJ, Brasil. Retrieved from https:/www.ens.edu.br/ arquivos/31 32015 gabriela xavier krull ribeiro seminario aplicacoes em asset liability management.pdf
Saad, N., \& Ribeiro, C.O. (2004). Modelos determinísticos de gestão de ativo/passivo: Uma aplicação no Brasil. Revista Contabilidade \& Finanças, 15(34), 50-62. https://doi.org/10.1590/S1519-70772004000100004

Santana,V.F., \&Costa,T.M.T.(2017). Thediscount ratein pensionassets and liabilities management. Brazilian Review of Finance, 15(4), 631-655. https://doi.org/10.12660/rbfin.v15n4.2017.66262

Santos, S. I. F., \& Lima, D. V. (2019). Perspectivas de adoção de modelos de asset and liability management (ALM) em regimes próprios de previdência social. REDECA - Revista Eletrônica do Departamento de Ciências Contábeis \& Departamento de Atuária e Métodos Quantitativos da FEA-PUC/SP, 6(1), 2143. https://doi.org/10.23925/2446-9513.2019v6i1p21-43

Sartori, R. L. (2015). Relevância da taxa de desconto atuarial na avaliação dos benefícios pós-emprego com características de benefício definido de previdência privada fechada e seus reflexos na patrocinadora (Master's thesis). Universidade Federal do Rio Grande do Sul, Faculdade de Ciências Econômicas, Porto Alegre, RS, Brazil. Retrieved from http://hdl.handle.net/10183/132907

Silva, C. M., Drumond, F. M. P., Silva, D. M. I., Pereira, V. H., \& Oliveira, C. V. (2016). Identificação dos disclosures do CPC 33 (R1) nas demonstraçoóes de empresas brasileiras do segmento de telefonia listadas na BM\&FBOVESPA. Revista de Auditoria Governança e Contabilidade - RAGC, 4(17), 133153. Retrieved from https://www.fucamp.edu.br/editora/ index.php/ragc/article/view/895

Silva, F. L., Chan, B. L., \& Martins, G. A. (2007). Uma reflexão sobre o equilíbrio dos planos de benefícios de caráter previdenciário a partir das demonstraçóes contábeis dos fundos de pensão. Revista de Informação Contábil, 1(1), 69-87. https://doi. org/10.34629/ufpe-iscal/1982-3967.2007.v1.69-87

Silva, M. A. F., Tinoco, P. P., \& Vieira, S. S. C. (2015). Benefícios pós-emprego e seus impactos nas demonstrações contábeis das empresas brasileiras. Registro Contábil, 6(3), 118135. Retrieved from https://www.seer.ufal.br/index.php/ registrocontabil/article/view/1654

Silva, W. A. M., Malaquias, R. F., \& Rech, I. J. (2020). Análise das variáveis que afetam o desempenho de carteira das entidades fechadas de previdência complementar brasileiras. Revista Contemporânea de Contabilidade, 17(44), 54-70. https://doi.org/10.5007/2175-8069.2020v17n44p54

Sousa, L. F. D., \& Costa, F. M. (2015, May). Equilíbrio atuarial dos planos previdenciários de benefício definido: Relação entre características dos fundos de pensão e a escolha de premissas atuariais. Anais do Congresso da Associação Nacional de Programas de Pós-Graduação em Ciências Contábeis, Curitiba, PR, Brazil, 9. Retrieved from http://legado.fucape.br/ public/producao cientifica/ $2 / \mathrm{mfc} 294 \% 20(2)$.pdf

Superintendência Nacional de Previdência Complementar. (2019). Relatório de Estabilidade da Previdência Complementar Setembro 2019. Retrieved from https://www.gov.br/economia/ pt-br/orgaos/entidades-vinculadas/autarquias/previc/ centrais-de-conteudo/publicacoes/relatorio-de-estabilidadeda-previdencia-complementar-rep/relatorio_de-estabilidadeda-previdencia-complementar-setembro-2019-1-5-1.pdf/ view 
Superintendência Nacional de Previdência Complementar. (2020). Demonstrativos atuariais. Retrieved from https://www. gov.br/economia/pt-br/orgaos/entidades-vinculadas/ autarquias/previc/acesso-a-informacao/dados-abertos/ demonstrativos-atuariais

Torres-Reyna, O. (2010). Getting started in fixed/random effects models using $R$. Princeton University, Data \& Statistical Services. Retrieved from https://www.princeton.edu/ - otorres/Panel101R.pdf

Varga, G. (2009). Teste de modelos estatísticos para a estrutura a termo no Brasil. Revista Brasileira de Economia, 63(4), 361-394. Retrieved from https://www.scielo.br/j/rbe/a/ jkcD6FP6pWhGvcMp8t6JhrP/abstract/?lang=pt\#

\section{Authorship}

\section{Sandro de Azambuja*}

Universidade Federal Fluminense, Faculdade de Administração e Ciências Contábeis, Departamento de Contabilidade

Rua São Paulo, n. 30, Campus do Valonguinho, Centro, 24020150, Niterói, RJ, Brazil

Universidade Federal do Rio de Janeiro, Instituto COPPEAD de Administração

Rua Pascoal Lemme, n. 355, Cidade Universitária, 21941-918, Rio de Janeiro, RJ, Brazil

E-mail: sandroazambuja@id.uff.br, sandro.azambuja@coppead.ufr.br

(D) https://orcid.org/0000-0002-0322-3168

\section{Carlos Heitor Campani}

Universidade Federal do Rio de Janeiro, Instituto COPPEAD de Administração

Rua Pascoal Lemme, n. 355, Cidade Universitária, 21941-918, Rio de Janeiro, RJ, Brazil

E-mail: carlos.heitor@coppead.ufrj.br

(D) https://orcid.org/0000-0003-1896-7837

* Corresponding Author

\section{Funding}

The author Carlos Heitor Campani would like to thank the following Brazilian institutions for financial support to his research: Brasilprev Research Chair, ENS (Escola de Negócios e Seguros), CNPq (National Council for Scientific and Technological Development), FAPERJ (Fundaçáo de Amparo à Pesquisa do Estado do Rio de Janeiro), and Quantum Finance (Data Provider).

\section{Conflict of Interests}

The authors have stated that there is no conflict of interest.

\section{Plagiarism Check}

The RAC maintains the practice of submitting all documents approved for publication to the plagiarism check, using specific tools, e.g.: iThenticate.
Vittas, D. (2010). Discount rates and the valuation of pension liabilities. World Bank.

World Bank. (2012). Brazil risk-based supervision (RBS) of Brazilian closed pension funds [Report No. 74907BR]. World Bank, Finance \& Private Sector Development. Retrieved from http://documents. worldbank.org/curated/pt/157551468228277255/ pdf/749070ESW0P1190C0disclosed030150130.pdf

\section{Authors' Contributions}

$1^{\text {st }}$ author: conceptualization (lead); data curation (lead); formal analysis (lead); investigation (lead); methodology (lead); project administration (lead); software (lead); writingoriginal draft (lead); writing-review \& editing (lead).

$2^{\text {nd }}$ author: conceptualization (supporting); formal analysis (supporting); investigation (supporting); methodology (supporting); project administration (supporting); supervision (lead); validation (supporting); visualization (supporting); writing-review \& editing (supporting).

\section{Copyrights}

RAC owns the copyright to this content.

\section{Peer Review Method}

This content was evaluated using the double-blind peer review process. The disclosure of the reviewers' information on the first page, as well as the Peer Review Report, is made only after concluding the evaluation process, and with the voluntary consent of the respective reviewers and authors.

\section{Data Availability}

The authors claim that all data and materials have been made publicly available through the Harvard Dataverse platform and can be accessed at:

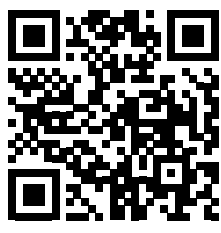

Azambuja, Sandro; Campani, Carlos Heitor, 2021, "Replication Data for: MAC: A Proposal for Consistent Actuarial Interest Rates in Pension Funds published by RAC-Revista deAdministração Contemporânea", Harvard Dataverse, V1. https://doi.org/10.7910/DVN/EZSUXE

RAC encourages data sharing but, in compliance with ethical principles, it does not demand the disclosure of any means of identifying research subjects, preserving the privacy of research subjects. The practice of open data is to enable the reproducibility of results, and to ensure the unrestricted transparency of the results of the published research, without requiring the identity of research subjects. 